\title{
Even after UVA-exposure will nitric oxide protect cells from reactive oxygen intermediate-mediated apoptosis and necrosis
}

\author{
CV Suschek ${ }^{1}$, K Briviba ${ }^{2}$, D Bruch-Gerharz ${ }^{3}$, H Sies ${ }^{2}$, \\ KD Kröncke ${ }^{1}$ and V Kolb-Bachofen ${ }^{\star, 1}$ \\ ${ }^{1}$ Research Group Immunobiology, Heinrich-Heine-University Düsseldorf, \\ D-40001 Düsseldorf, Germany \\ 2 Institute of Physiological Chemistry I, Heinrich-Heine-University Düsseldorf, \\ D-40001 Düsseldorf, Germany \\ 3 Department of Dermatology, and Biologisch-Medizinisches \\ Forschungszentrum, Heinrich-Heine-University Düsseldorf, D-40001 \\ Düsseldorf, Germany \\ * Corresponding author: Prof. Dr. V Kolb-Bachofen, Institute of Immunobiology \\ Bldg. 14.80, Heinrich-Heine-University Düsseldorf, P.0. Box 101007 \\ D-40001 Düsseldorf, Germany. Tel:+49-211-81-19184; \\ Fax:+49-211-81-19532; E-mail: bachofen@uni-duesseldorf.de
}

Received 1.8.00; Revised 18.12.00; accepted 20.12.00

Edited by A Finazzi-Agro

\begin{abstract}
Reactive oxygen species (ROS) play a pivotal role in UVAinduced cell damage. As expression of the inducible nitric oxide synthase (iNOS) is a normal response of human skin to UV radiation we examined the role of nitric oxide (NO) as a protective agent during or even after $\mathrm{UVA}_{1}$ - or ROS-exposure against apoptosis or necrosis of rat endothelial cells. When added during or up to $2 \mathrm{~h}$ subsequent to $\mathrm{UVA}_{1}$ or ROS exposure the NO-donor S-nitroso-cysteine (SNOC) at concentrations from $100-1000 \mu \mathrm{M}$ significantly protects from both apoptosis as well as necrosis. The NO-mediated protection strongly correlates with complete inhibition of lipid peroxidation (sixfold increase of malonedialdehyde

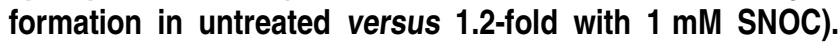
NO-mediated protection of membrane function was also shown by the inhibition of cytochrome $c$ leakage in UVA treated cells, a process not accompanied by alterations in Bax and Bcl-2 protein levels. Thus, the experiments presented demonstrate that NO exposure during or even after a ROSmediated toxic insult fully protects from apoptosis or necrosis by maintaining membrane integrity and function. Cell Death and Differentiation (2001) 8, 515-527.
\end{abstract}

Keywords: UVA ${ }_{1}$; Rose Bengal; nitric oxide; NO donors; singlet oxygen; reactive oxygen species

Abbreviations: $\mathrm{BHT}$, butylated hydroxytoluene; $\mathrm{EC}$, endothelial cells; iNOS, inducible nitric oxide synthase; NO, nitric oxide; RB/hv, Rose Bengal plus visible light; ROS, reactive oxygen species; SNOC, S-nitrosocysteine; SOD, superoxide dismutase; $U_{V A}$, ultraviolet radiation $\mathrm{A}_{1}$

\section{Introduction}

Ultraviolet radiation is divided into three regions: UVC $(190-290 \mathrm{~nm})$, UVB $(290-320 \mathrm{~nm})$ and UVA (320$400 \mathrm{~nm}$ ). Effects on cells by UV radiation of shorter wavelengths, UVB and UVC, have been extensively investigated in terms of direct effects on DNA. ${ }^{1}$ UVA was initially perceived as innocuous to skin however, numerous reports recently have demonstrated cytotoxic effects after exposure of eukaryotic cells to UVA radiation as a consequence of oxidative stress. UVA-induced oxidative damage has been reported for several target molecules as well as organelles. ${ }^{2,3}$

A plethora of anti-oxidant and anti-apoptotic defense mechanisms exists in mammalian cells, such as enzymes or compounds which quench or remove reactive oxygen species (ROS), proteins with chaperone activity such as heat shock proteins ${ }^{4}$ or proteins of the bcl-2 family which have been shown to serve as potent anti-apoptotic factors. ${ }^{5}$ Recent evidence suggests that the signal molecule nitric oxide (NO) can also act as an antiapoptotic agent. ${ }^{6} \mathrm{NO}$ and equivalent amounts of citrulline are synthesized from the guanidino nitrogen of L-arginine by NO synthases (NOS) found in endothelial cells, neurons and upon activation by proinflammatory stimuli in most cell types. The NOS enzyme family consists of three isoenzymes: constitutively expressed and calcium/calmodulin-regulated are the endothelial (ecNOS) and the neuronal (ncNOS) isoenzymes which produce regulated low amounts of $\mathrm{NO}$ for short periods of time, whereas the cytokine-inducible and calcium-independent isoenzyme (iNOS) synthesizes NO for extended periods of time. ${ }^{7,8}$

Cytokines are known modulators of endothelial cell functions during inflammatory processes. One prominent effect that cytokines can exert in endothelial cells is the induction of iNOS and thus high-output NO synthesis. ${ }^{9}$ Recently, we have shown that exposure well before $\mathrm{UVA}_{1}$-irradiation of endothelial cells to $\mathrm{NO}$ either endogenously synthesized by iNOS after challenge by proinflammatory cytokines or applied exogenously in the form of a NO-donor fully protects cells from $U_{V A}$-induced cell damage. The protective effect strongly correlated with a NO-induced increase in Bcl-2 protein expression. ${ }^{10}$ As in the vivo situation NO-generation by iNOS will start after skin exposure to sunlight, we now tested whether and by which mechanisms a protection after UV-irradiation is exerted. We show a strong protective effect of NO even when added during or up to $2 \mathrm{~h}$ after the toxic insult. This timing does not allow for increased $\mathrm{Bcl}-2$ expression and we here demonstrate that nitric oxide acts as a powerful inhibitor of ROS-mediated lipid peroxidation with a concomitant arrest of $\mathrm{Bax}$ and $\mathrm{Bcl}-2$ independent 
mitochondrial cytochrome $c$ release. Thus data provide further evidence for the protective role of NO synthesis in skin helping to prevent cellular damage after UVexposure.

\section{Results}

\section{Characterization of endothelial cell death pathways}

Irradiation of EC with UVA 1 leading to endothelial apoptotic cell death in a dose-dependent manner has been described previously. ${ }^{10}$ Using irradiation with a dose of $10 \mathrm{~J} / \mathrm{cm}^{2}$ UVA, the appearance of apoptotic markers becomes significant after a delay of 4-8 h (Figure $1 \mathrm{~A}$ ) as quantified by Hoechst staining and in situ nick translation. In addition, $U_{V A}$-induced cell death is completely inhibited by incubation with the caspase inhibitor Z-VAD (Figure 1B) as additional prove for apoptosis.

We also treated cells with singlet oxygen, generated by photoexcitation after pre-loading with Rose Bengal (RB/ $\mathrm{h} v$ ). Dependent on the concentration of Rose Bengal cell death was maximal at $1.8 \mu \mathrm{M} \mathrm{RB} / \mathrm{h} v$, with half maximal induction of cell death at $0.9 \mu \mathrm{M} \mathrm{RB} / \mathrm{h} v$ (Figure 2A). Interestingly, the mode of cell death was necrosis exclusively as evidenced by the rapid onset of cell death which was nearly complete after 2-4 h (Figure 2B) but also by the complete lack of apoptotic nuclear morphology as well as failure of protection by the caspase inhibitor ZVAD (Figure 2C). Because of its lipophilic character, incubation of endothelial cells with Rose Bengal led to its enrichment into intracellular membranes predominantly ${ }^{11}$ (Figure 2D).

\section{Protection by antioxidative agents}

Adding various antioxidants we elucidated the role of ROS during $\mathrm{UVA}_{1}$-irradiation or Rose Bengal treatment. Agents were added to cell cultures during $\mathrm{UVA}_{1}$-irradiation or $\mathrm{RB} / \mathrm{h} v$ treatment and the numbers of viable cells were determined after $24 \mathrm{~h}$ of culture. Deuterium oxide $\left(\mathrm{D}_{2} \mathrm{O}\right)$ prolonging the lifetime of ${ }^{1} \mathrm{O}_{2}$ significantly enhanced $E C$ death after UVA irradiation or $\mathrm{RB} / \mathrm{h} v$-challenge. Conversely, compounds quenching singlet oxygen, i.e. $\mathrm{NaN}_{3}(20 \mathrm{mM})$, histidine (40 mM), and imidazole $(40 \mathrm{mM})$ exerted a significant protection (Figure $3 \mathrm{~A}$ ) suggesting the involvement of singlet oxygen generation early in $U_{V A}$-induced cell death, as has been reported previously. $3,12,13$ All four compounds gave the same exacerbation or augmentation also in $R B / h v$ induced toxicity. Next the involvement of superoxide anion generation was screened by adding the $\mathrm{O}_{2}{ }^{-}$-quencher MnTBAP $(80 \mu \mathrm{M})$ or DETC $(1 \mathrm{mM})$, an inhibitor of the intracellular SOD. Both, $\mathrm{O}_{2} \cdot-$-depletion by MnTBAP or inhibition of its conversion by SOD to $\mathrm{H}_{2} \mathrm{O}_{2}$ fully protected cells from induced apoptosis or necrosis (Figure $3 \mathrm{~B}$ ). In contrast, addition of SOD $(1000 \mathrm{U} / \mathrm{ml})$ significantly enhanced cell death, while heat-inactivated SOD was without effect (Figure 3B) indicating that $\mathrm{H}_{2} \mathrm{O}_{2}$ more than $\mathrm{O}_{2}{ }^{-}$may represent the toxic agent during UVA-irradiation or $\mathrm{RB} / \mathrm{h} v$ treatment. This is supported by our findings that addition of catalase $(2000 \mathrm{U} / \mathrm{ml})$ during the toxic inputs was fully
$\mathbf{A}$

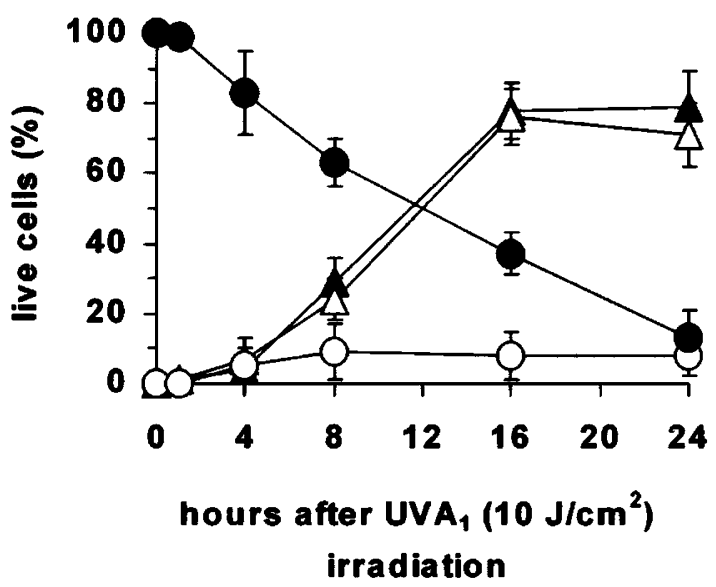

B

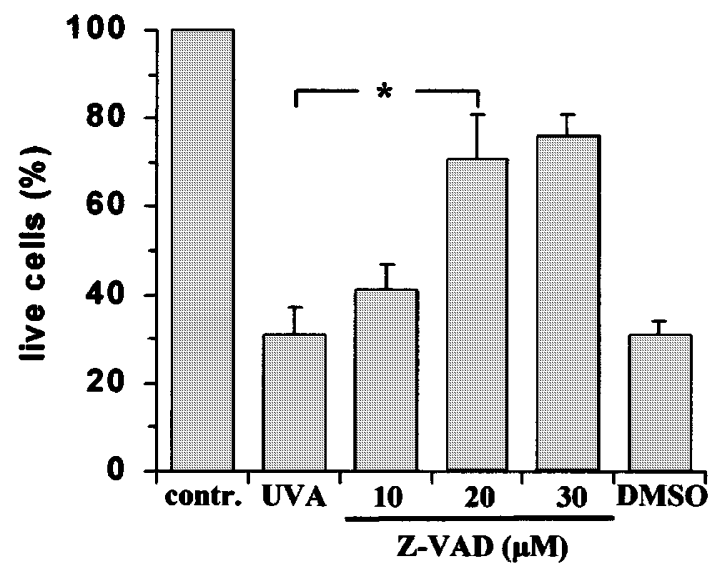

Figure $1 \mathrm{UVA}_{1}$ irradiation of endothelial cells leads to cell death via apoptosis. Resting endothelial cells (EC) were exposed to $U_{V A}$ radiation and number of viable $(\mathbf{O})$, apoptotic $(\triangle, \boldsymbol{\Delta})$, and necrotic cells $(O)$ was determined at times indicated. Increasing $U_{V A}$ intensities after $24 \mathrm{~h}$ lead to increasing number of cells with nuclear chromatin condensation and nuclear fragmentation as indicators for apoptosis. (A), Time-course of UVA $A_{1}$-induced apoptotic events after $U_{V A}$-irradiation with $10 \mathrm{~J} / \mathrm{cm}^{2}$ as determined by appearance of cells with pyknotic nuclei, nuclear chromatin condensation, and nuclear fragmentation in Hoechst 33343 stained cells $(\triangle)$ or DNA strand breaks visualized by in situ nick translation $(\boldsymbol{\Delta})$. At and later than $16 \mathrm{~h}$ after $U_{V A}$-irradiation, the number of apoptotic nuclei is significantly increased and $24 \mathrm{~h}$ after irradiation with $10 \mathrm{~J} / \mathrm{cm}^{2}$ approximately $80 \%$ of cells are apoptotic and about $10 \%$ are necrotic as judged by propidium iodide staining. (B), Cultures were also incubated with a pan-caspase inhibitor at concentrations indicated prior to $U_{V A}$-irradiation $\left(8 \mathrm{~J} / \mathrm{cm}^{2}\right)$ and the relative number of viable cells was determined by neutral red staining as described in Materials and Methods. Z-VAD fully protects from $U_{V A}$-induced $\left(10 \mathrm{~J} / \mathrm{cm}^{2}\right)$ cell death in a concentration dependent manner. Values are the mean \pm S.D. of $3-12$ individual experiments ${ }^{*}, P<0.001$

protective, whereas the catalase inhibitor 3-amino-1,2,4triazole $(500 \mu \mathrm{M})$ enhanced cytotoxicity (Figure $3 \mathrm{C})$. The antioxidant $\mathrm{BHT}(10 \mu \mathrm{M})$, an strong inhibitor of lipid peroxidation, fully protects (Figure 3D) whereas neither DMSO $(100 \mathrm{mM})$ nor mannitol $(100 \mathrm{mM})$ both scavenging of $\mathrm{OH}$ influenced cell death rates indicating that $\mathrm{OH}$ appears not to contribute to $\mathrm{UVA}_{1}$-or $\mathrm{RB} / \mathrm{h} v$-induced cell death (data not shown). 


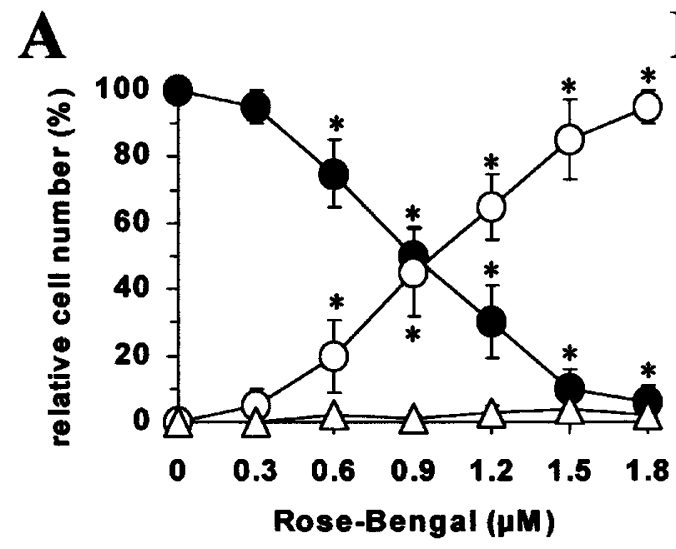

B
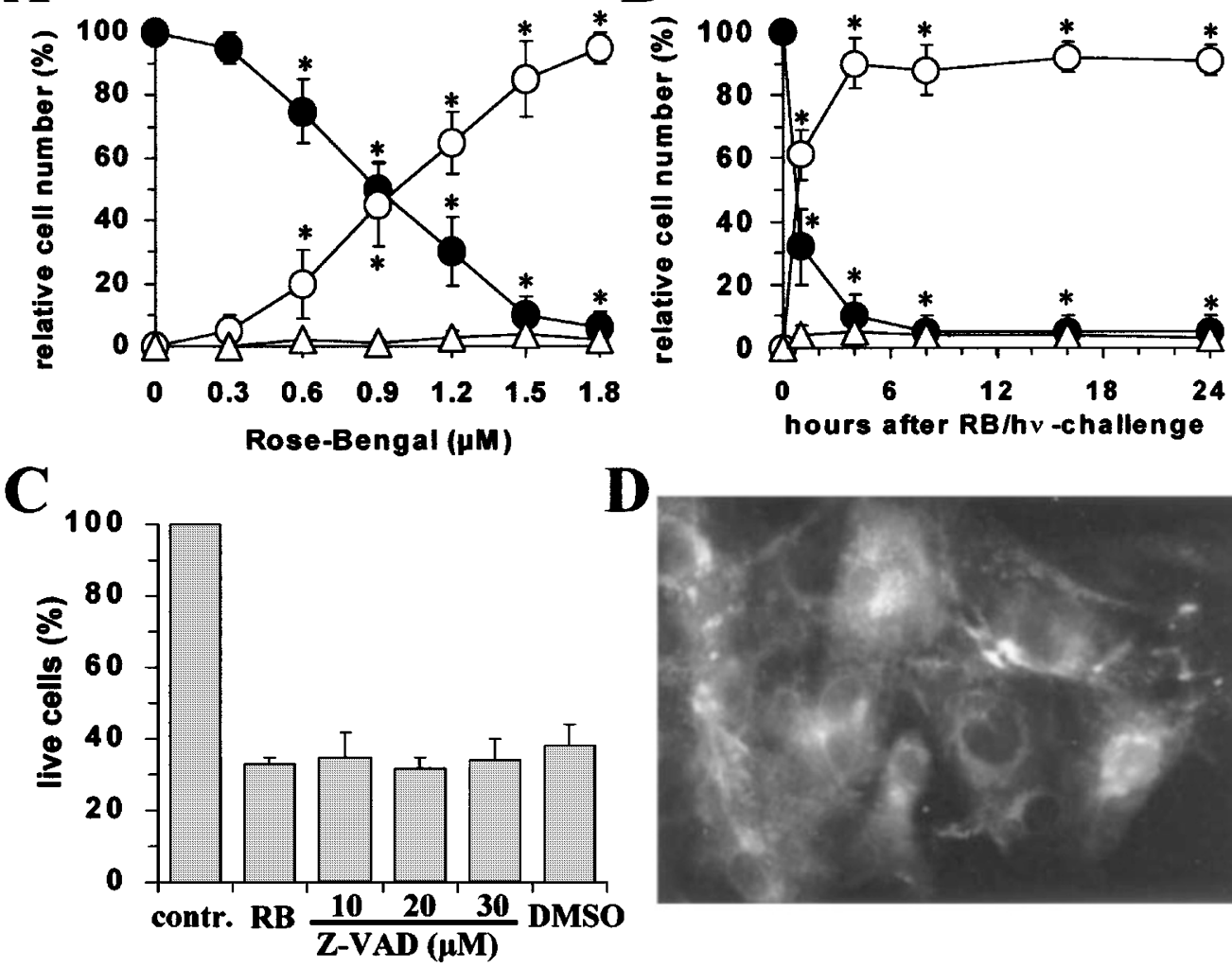

D

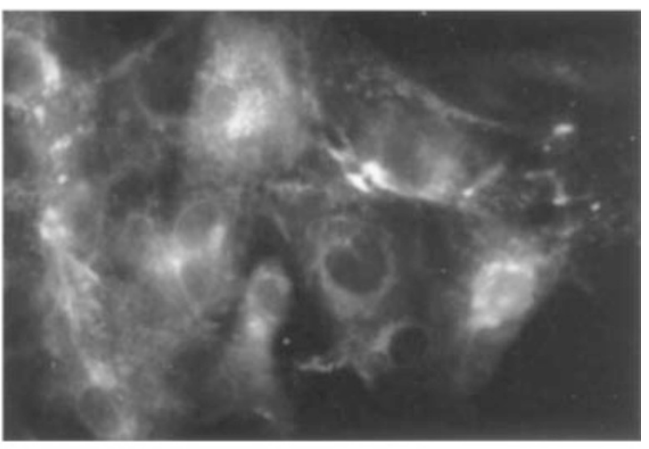

Figure 2 Singlet oxygen-generation in endothelial cells leads to cell death via necrosis. Resting endothelial cells (EC) were pre-loaded with Rose Bengal at concentrations indicated and singlet oxygen generation was induced by irradiation with visible light (RB/hv). The relative number of viable $(\mathbf{O})$, necrotic $(O)$, and apoptotic cells $(\triangle)$ was determined as in Figure 1. (A), Endothelial cell death rates correlated with concentration of RB. Death occurred via necrosis as seen by the increase of propidium iodide positive cells $(\triangle)$ and failure to detect apoptotic nuclei with $\mathrm{H} 33342$ at any of the RB concentrations used ( $\triangle$ ). (B), Time-course of RB/ $\mathrm{h} v$-induced $(1.5 \mu \mathrm{M})$ cell death shows an early and rapid onset of necrotic cell death $(O)$ with apoptosis in $\leqslant 5 \%$ of the cells only $(\triangle)$. (C), The caspase inhibitor ZVAD showed no protection from RB/hv-induced cell death as a further evidence for necrosis. (D), A fluorescence photomicrograph of a culture incubated with Rose Bengal clearly demonstrates a strong enrichment of the dye predominantly in membrane of the nucleus, mitochondria, as well as endoplasmatic reticulum. Magnifications: $\times 650$. Values are the mean \pm S.D. of $3-8$ individual experiments. ${ }^{*}, P<0.001$

\section{Exogenous NO present during the experimental procedure fully protects from both apoptosis caused by UVA $\mathrm{A}_{1}$ and necrosis caused by singlet oxygen}

We had shown previously that the presence of $\mathrm{NO}$ for $24 \mathrm{~h}$ prior to UVA fully protected cells from apoptosis. ${ }^{10}$ We now investigated whether NO could also protect when present during treatment and whether it would exacerbate or augment $\mathrm{RB} / \mathrm{h} v$-induced necrosis. During UVA treatment cells were incubated with the NO donors SNOC or DETA/ NO or with the respective controls cysteine or DETA. SNOC, in a concentration-dependent manner, lowered or completely inhibited $U_{V A}$-induced apoptosis as well as RB/ $\mathrm{h} v$-induced necrosis of EC. Concentrations of SNOC $\geqslant 100 \mu \mathrm{M}$ exerted substantial protection (Figure 4A,B),

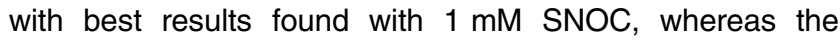
control compound cysteine was without effect (Figure 4A,B). Experiments using the NO donor DETA/NO gave similar results (Figure $4 \mathrm{C}, \mathrm{D}$ ).

\section{Time window for protection by nitric oxide or antioxidants added after the insults}

To examine whether the various agents tested will also protect when added after $U_{V A}$-irradiation or singlet oxygen treatment, antioxidants or nitric oxide were added to EC cultures at different time points after the treatments.

After $U_{V A}$-irradiation (Figure $5 \mathrm{~A}$ ) or Rose Bengalchallenge (Figure $5 \mathrm{~B}), \mathrm{NaN}_{3}(20 \mathrm{mM})$ ceased to protect when added as early as $5 \mathrm{~min}$ after $\mathrm{UVA}_{1}$. MnTBAP $(80 \mu \mathrm{M})$ showed a significant protection when added up to $15 \mathrm{~min}$ after the toxic stimuli. In contrast, catalase $(2000 \mathrm{U} / \mathrm{ml})$ or BHT $(10 \mu \mathrm{M})$ show comparable timecourses of protection which is significant when added to cell cultures as late as $2 \mathrm{~h}$ after $U_{V A} A_{1}$-challenge or $1 \mathrm{~h}$ after $\mathrm{RB} / \mathrm{h} v$-treatment. Examining the protective time window for $\mathrm{NO}$ by addition of the NO-donor SNOC $(1 \mathrm{mM})$ at different time intervals after $\mathrm{UVA}_{1}$-irradiation (Figure $5 \mathrm{~A}$ ) or $\mathrm{RB} / \mathrm{h} v$ treatment (Figure $5 \mathrm{~B}$ ) we find a similar time window for protection against $\mathrm{UVA}_{1}$-induced apoptosis or ${ }^{1} \mathrm{O}_{2}$-induced 

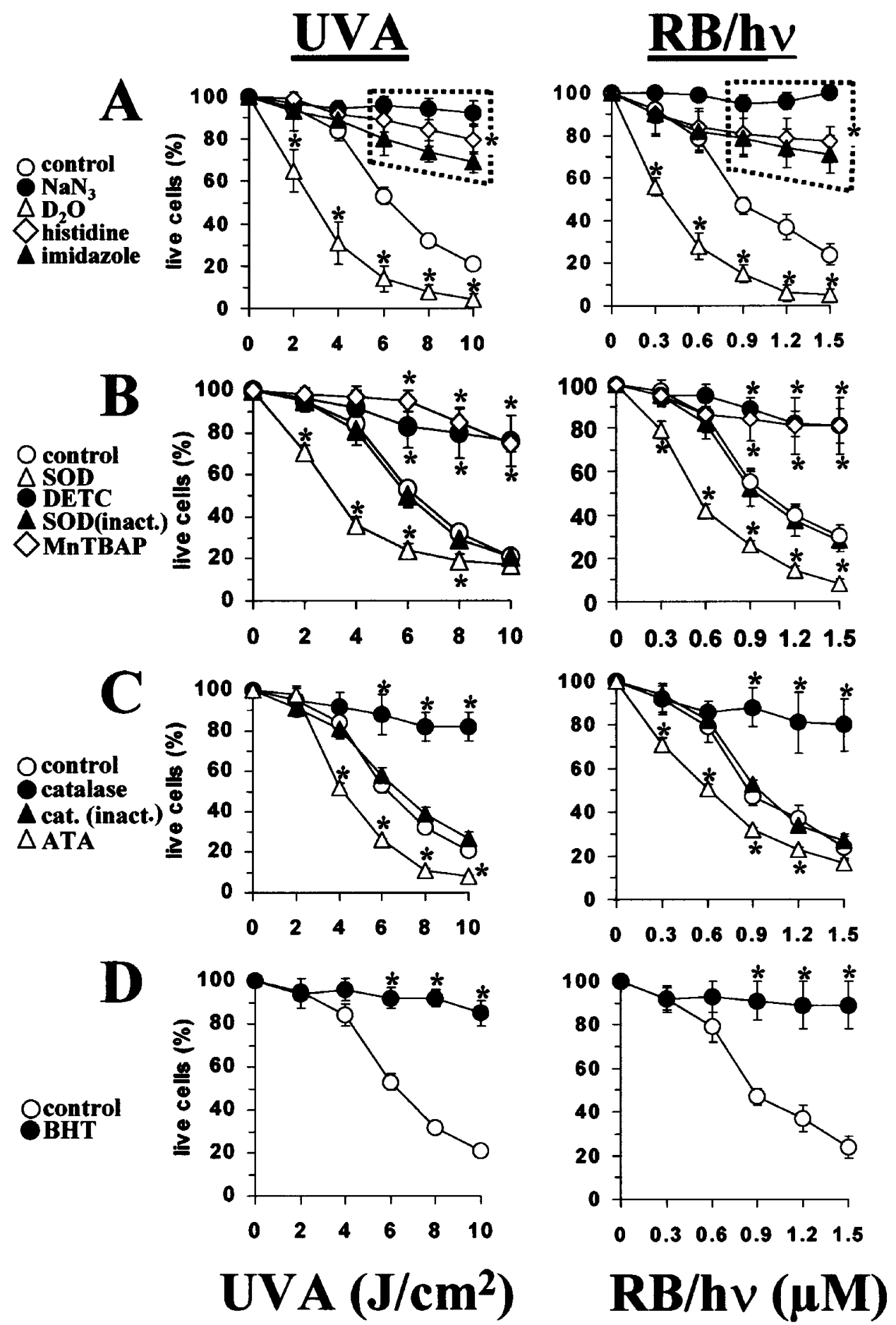

Figure 3 Inhibiting formation of reactive oxygen species will protect from cell death. To examine the role of reactive oxygen species (ROS) during UVA $A_{1}$ irradiation or RB/hv treatment, various compounds with specific ROS-inhibitory activities were added during $\mathrm{UVA}_{1}$ or RB/hv and the number of live cells was determined as described in Material and Methods. (A), Quenchers of ${ }^{1} \mathrm{O}_{2}$, i.e. $\mathrm{NaN}_{3}(\bullet ; 20 \mathrm{mM})$, histidine $(\diamond, 40 \mathrm{mM})$, and imidazole $(\boldsymbol{\Delta} ; 40 \mathrm{mM})$ protected (dotted cage) whereas prolongation of ${ }^{1} \mathrm{O}_{2}$ half-life $\left(\mathrm{D}_{2} \mathrm{O} ; \triangle\right)$ enhanced cell death. $(\mathbf{B})$, Removal of superoxide anions $\left(\mathrm{O}_{2}^{-}\right)$by $\operatorname{MnTBAP}(\diamond ; 80 \mu \mathrm{M})$ and inhibition of intracellular SOD by DETC $(\bullet ; 1 \mathrm{mM})$ also protected whereas SOD $(\triangle ; 1000 \mathrm{U} / \mathrm{ml})$ significantly enhanced cell destruction, while heat-inactivated SOD had no effect (A). (C). Catalase-mediated $(\bullet ; 2000 \mathrm{U} / \mathrm{ml})$ degradation of $\mathrm{H}_{2} \mathrm{O}_{2}$ also protects while heat-inactivated catalase $(\boldsymbol{A})$ was without effect and inhibition of endogenous catalase by 3-amino-1,2,4-triazole $(\triangle$; ATA, $500 \mu \mathrm{M})$ strongly enhanced cytotoxicity. (D), Butylated hydroxytoluene $(\mathbf{\bullet} ; \mathrm{BHT}, 10 \mu \mathrm{M})$, an inhibitor of lipid peroxidation also fully protects. In all graphs sham treated controls are shown (O). Values are the mean \pm S.D. of $3-10$ individual experiments. ${ }^{*}, P<0.001$ 

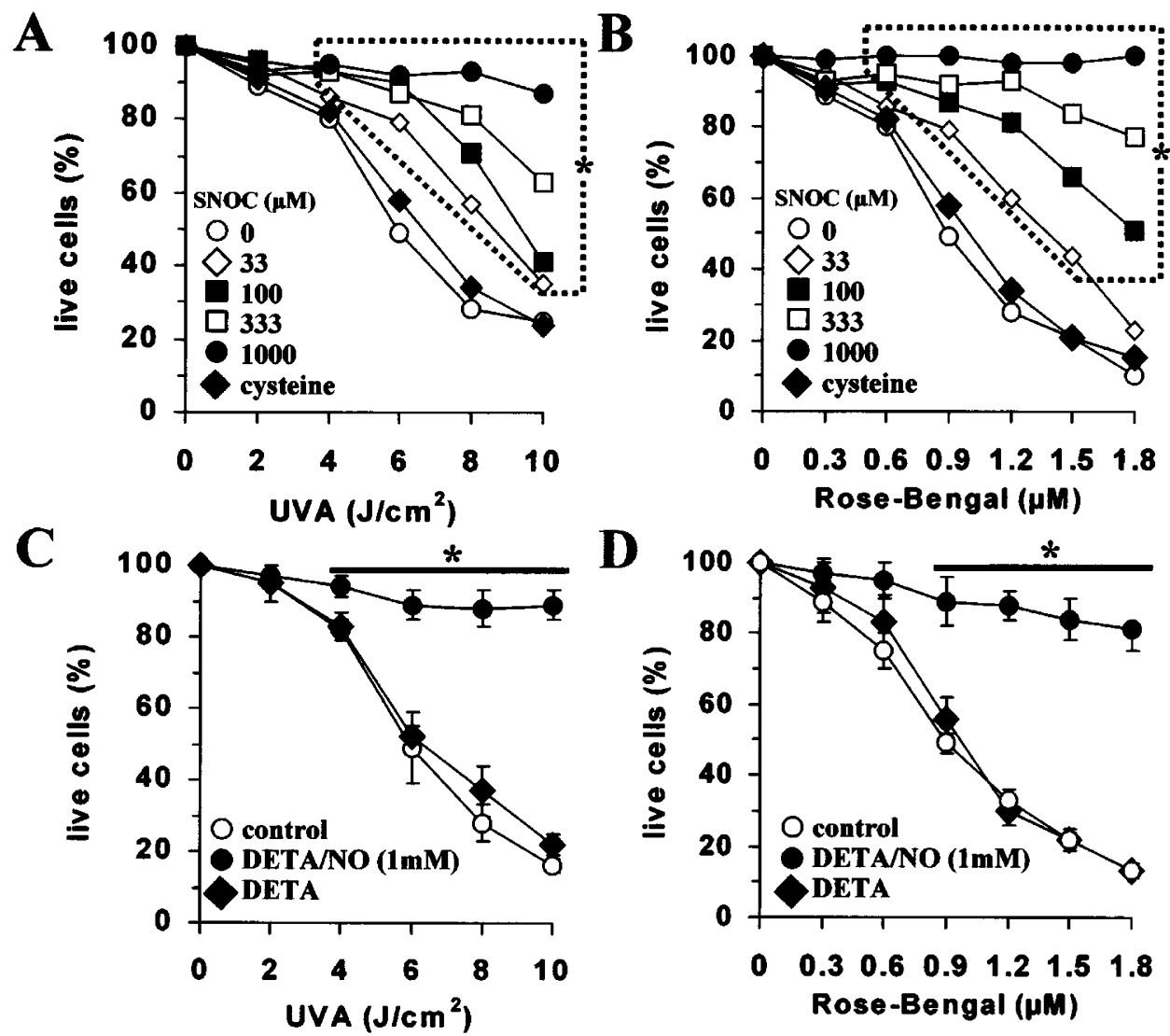

D

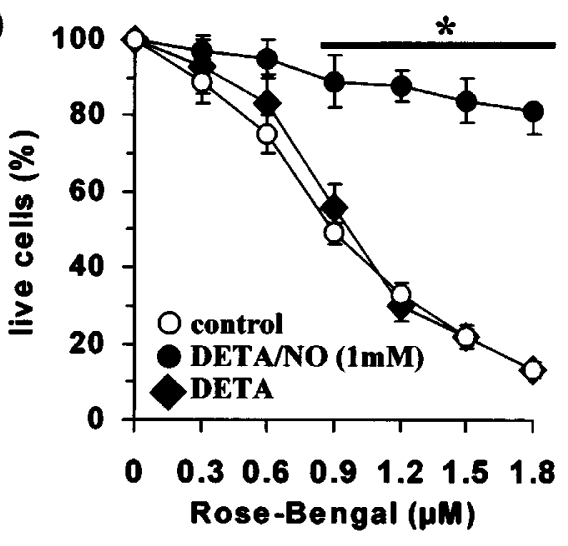

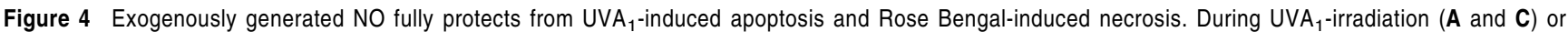
singlet oxygen-challenge via RB/hv (B and $\mathbf{D})$ resident endothelial cells (EC) were incubated with S-nitrosocysteine (SNOC) (A and B) or DETA/NO (C and D) at concentrations of $0 \mu \mathrm{M}(\bigcirc), 33 \mu \mathrm{M}(\diamond), 100 \mu \mathrm{M}(\mathbf{\square}), 333 \mu \mathrm{M}(\square), 1,000 \mu \mathrm{M}(\mathbf{O})$ or the control compounds cysteine or DETA $(\diamond, 1000 \mu \mathrm{M}$ each). After $24 \mathrm{~h}$ of incubation the number of living cells was determined using Neutral-Red. (A, B), At concentrations $\geqslant 100 \mu \mathrm{M}$ SNOC-mediated protection against UVA -induced $^{-}$ apoptosis or RB/hv-induced necrosis was significant (dotted cage) and a strong correlation between the SNOC concentration used and protection from UVA -or $\mathrm{RB} / \mathrm{h} v$-induced cell death is found $\left(\mathrm{R}^{2}=0.957\right.$ for $\mathrm{UVA}_{1}$ or $\mathrm{R}^{2}=0.979$ for $\left.\mathrm{RB} / \mathrm{h} v\right)$. Nearly complete protection was seen with $1000 \mu \mathrm{M}$ SNOC, whereas the control compound cysteine showed no protective effect. (C, D), Experiments using the NO donor DETA/NO or the control DETA gave similar results. Values are the mean \pm S.D. of $3-8$ individual experiments. * $P<0.001$

necrosis, which parallels the protection seen after incubation with catalase or BHT.

\section{Protection by NO is not due to reaction with or quenching of ROS}

Using dihydrorhodamine $123(10 \mu \mathrm{M})$ a fluorescent dye for $\mathrm{H}_{2} \mathrm{O}_{2}$ detection we examined the input of $\mathrm{NO}$ as potential quencher or reaction partner of the ROS formed after $U_{V A}$ irradiation $\left(8 \mathrm{~J} / \mathrm{cm}^{2}\right)$ or ${ }^{1} \mathrm{O}_{2}$ generation $(1.5 \mu \mathrm{M} \mathrm{RB} / \mathrm{h} v)$. UVA $\mathrm{UA}_{1}$ exposure of otherwise untreated EC (Figure $6 \mathrm{~A}$ ) led to an increase in intracellular fluorescence (Figure 6B). In contrast, presence of ${ }^{1} \mathrm{O}_{2}$ quenchers (Figure $6 \mathrm{C}$, histidine, $40 \mathrm{mM}$ ), inhibition of endogenous SOD with $1 \mathrm{mM}$ diethyldithiocarbamate (Figure 6D), $\mathrm{O}_{2}{ }^{-}$depletion by $80 \mu \mathrm{M}$ MnTBAP (Figure $6 \mathrm{~F}$ ) or $\mathrm{H}_{2} \mathrm{O}_{2}$ depletion by $2000 \mathrm{U} / \mathrm{ml}$ catalase (Figure $6 \mathrm{G}$ ) fully inhibited rhodamine 123 formation, whereas heat-inactivated catalase had no inhibitory effect (Figure $6 \mathrm{H}$ ). In contrast, neither the presence of $10 \mu \mathrm{M} \mathrm{BHT}$ (Figure 6I) nor of $1 \mathrm{mM}$ SNOC (Figure $6 \mathrm{~J}$ ) inhibited the $\mathrm{UVA}_{1}$-or the $\mathrm{RB} / \mathrm{h} v$-induced fluorescence, suggesting that neither $\mathrm{BHT}$ nor NO will react directly with the ROS species involved. Control incubations of irradiated cells with SNOC or any of the other substances used (data not shown) did not result in increased cellular fluorescence, while incubation of cells with $\mathrm{H}_{2} \mathrm{O}_{2}(0.3 \mathrm{mM}$ for $15 \mathrm{~min}$ ) resulted in a pronounced fluorescence signal (Figure $6 \mathrm{~L}$ ). Besides reacting with $\mathrm{H}_{2} \mathrm{O}_{2}$, dihydrorhodamine 123 may also react with peroxynitrite a reaction product of $\mathrm{NO}$ and $\mathrm{O}_{2}-.{ }^{14}$ To validate this possibility we incubated UVA or Rose Bengal treated cells with a SOD inhibitor exactly as already shown in Figure 6D but in the presence of the NO-donor SNOC $(1 \mathrm{mM})$. As shown in Figure $6 \mathrm{~K}$, no apparent increase in mitochondrial fluorescence could be observed further corroborating the notion that under the conditions used peroxynitrite will not be produced. Results obtained with the $\mathrm{RB} / \mathrm{h} v$-system were similar (data not shown).

\section{Nitric oxide fully protects from hydrogen peroxide induced toxicity}

Data presented above indicate that $\mathrm{H}_{2} \mathrm{O}_{2}$ formed enzymatically or non-enzymatically from ${ }^{1} \mathrm{O}_{2}$ or $\mathrm{O}_{2} \cdot-$ may represent a late ROS product involved in cell death mediated by $U_{V A}{ }^{-}$ irradiation or ${ }^{1} \mathrm{O}_{2}$-challenge. Thus, we examined the effects 


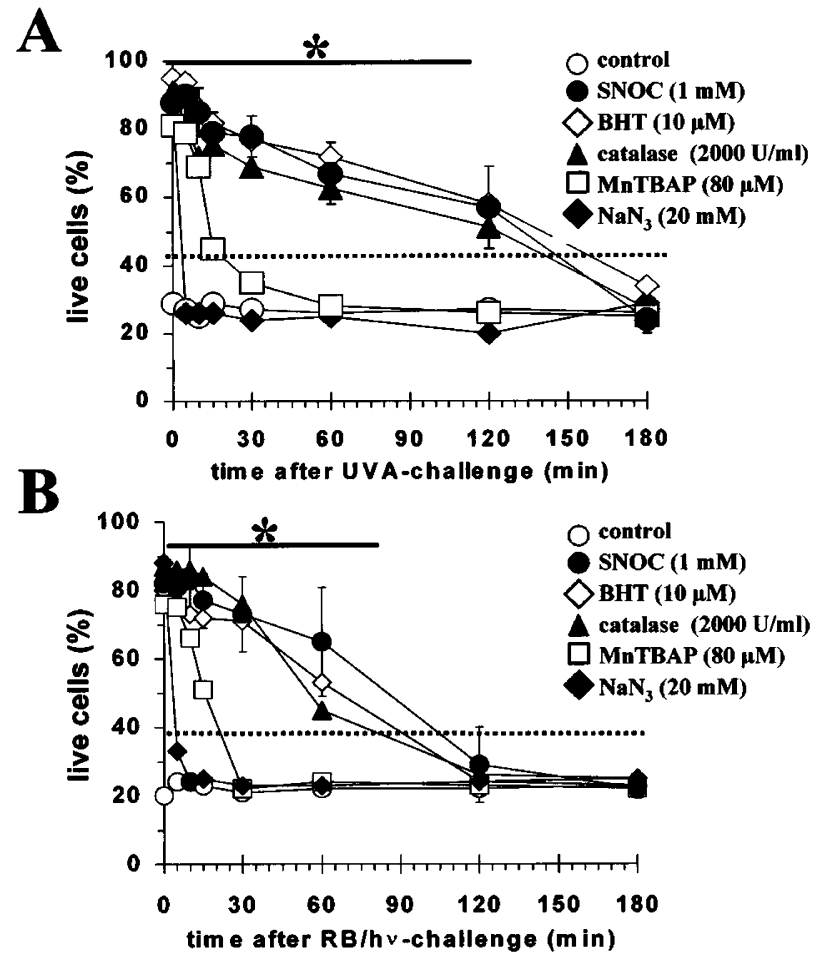

Figure 5 Time window for protection by antioxidants or NO added after the insults. To examine whether the various agents tested will also protect when added after $U_{V A}$-irradiation or singlet oxygen treatment antioxidants used in Figure 3 or the NO-donor S-nitroso-cysteine (1 mM SNOC) were added to the cultures at different time points after the treatments. (A), After $U_{V A}$-irradiation $\left(8 \mathrm{~J} / \mathrm{cm}^{2}\right), \mathrm{NaN}_{3}(\diamond ; 20 \mathrm{mM})$ protect only when present during the treatments. MnTBAP $(\square, 80 \mu \mathrm{M})$ prevented cell death when added up to $15 \mathrm{~min}$ later. Catalase $(\boldsymbol{\Delta} ; 2000 \mathrm{U} / \mathrm{ml})$ or butylated hydroxytoluene $(\diamond, \mathrm{BHT}, 10 \mu \mathrm{M})$ show comparable time-courses of protection when added as late as $2 \mathrm{~h}$ later. The NO donor S-nitrosocysteine (0; SNOC, $1 \mathrm{mM}$ ) showed comparable timecourses of protection as seen with catalase or the lipid peroxidation inhibitor $\mathrm{BHT}$ and protects even when added $2 \mathrm{~h}$ after $U_{V A_{1}}$-challenge. $O$, sham treated controls. (B), Analogous results were obtained with $\mathrm{RB} / \mathrm{h} v$-treated $\mathrm{EC}$ albeit with a shortened time scale. Values are the mean \pm S.D. of $3-8$ individual experiments. Values above the dotted line are statistically significant: *, $P<0.001$

of exogenously applied nitric oxide ( $1 \mathrm{mM} \mathrm{DETA/NO}$ ) or catalase $(4000 \mathrm{U} / \mathrm{ml})$ on $\mathrm{H}_{2} \mathrm{O}_{2}$-induced endothelial cell death, respectively. Incubation of endothelial cells with $\mathrm{H}_{2} \mathrm{O}_{2}$ for $24 \mathrm{~h}$ (Figure 7A) led to concentration-dependent cell death. Maximal toxicity was detected after incubation with $0.9 \mathrm{mM}$, half-maximal with $0.7 \mathrm{mM} \mathrm{H}_{2} \mathrm{O}_{2}$. Hydrogen peroxide-induced cell death was strongly reduced in the presence of catalase as well as in the presence of DETA/NO, whereas the controls DETA alone or heat-inactivated catalase had no effects.

Furthermore, with the half-maximal toxic dose of $0.7 \mathrm{mM}$ $\mathrm{H}_{2} \mathrm{O}_{2}$ DETA/NO was protective even when added $90 \mathrm{~min}$ after the toxic stimulus, whereas with the maximal dose of $0.9 \mathrm{mM} \mathrm{H}_{2} \mathrm{O}_{2}$ DETA/NO at a concentration of $1 \mathrm{mM}$ was not efficient enough to protect from cell death (Figure 7B).

\section{NO inhibits lipid peroxidation}

The results presented so far suggest lipid peroxidation as a crucial step in cell destruction. Therefore, endothelial cells were treated in the absence or presence of the various additives and lipid peroxidation was analyzed by determining the amount of malonedialdehyde formed. Results show a close correlation between $\mathrm{UVA}_{1}$ - or $\mathrm{H}_{2} \mathrm{O}_{2}$-induced apoptosis or $\mathrm{RB} / \mathrm{h} v$-induced necrosis and lipid peroxidation: As demonstrated in Figure $8 \mathrm{~A}, \mathrm{UVA}_{1}$-irradiation as well as ${ }^{1} \mathrm{O}_{2}$ generation from $\mathrm{RB} / \mathrm{h} v$ led to a highly significant increase in endothelial lipid peroxidation as evidenced by the amount of MDA formation. All substances which were shown to protect from apoptosis or necrosis (1 mM SNOC, $20 \mathrm{mM} \mathrm{NaN}, 10 \mu \mathrm{M} \mathrm{BHT}, 2000 \mathrm{U} / \mathrm{ml}$ catalase, $1 \mathrm{mM}$ DETC, $80 \mu \mathrm{M}$ MnTBAP) fully protected from lipid peroxidation. In addition, promoting induced cell death by addition of SOD or $\mathrm{D}_{2} \mathrm{O}$ further enhanced lipid peroxidation, whereas the control compounds did not affect the levels of lipid peroxidation. Furthermore, incubation of endothelial cells with $\mathrm{H}_{2} \mathrm{O}_{2}(0.9 \mathrm{mM})$ led to an approximately eightfold increase in lipid peroxidation, whereas incubation with hydrogen peroxide in the presence of $1 \mathrm{mM} D E T A / N O$, $10 \mu \mathrm{M}$ BHT or $2000 \mathrm{U} / \mathrm{ml}$ catalase significantly reduced formation of lipid peroxides to control values, respectively (Figure 8B).

We also examined the role of $\mathrm{NO}$ as an inhibitor of lipid peroxidation in a cell-free model using liposomes and the ${ }^{1} \mathrm{O}_{2}$ releasing endoperoxide $\mathrm{NDPO}_{2}(20 \mathrm{mM})$ as an inducer of lipid peroxidation. As exogenous $\mathrm{NO}$ source we used the $\mathrm{NO}$ donor MAHMA/NO (5 mM). Thermal decomposition of $\mathrm{NDPO}_{2}$ at $37^{\circ} \mathrm{C}$ led to a significant $6-11$-fold increase in lipid peroxidation which was completely inhibited by the NO-donor MAHMA/NO, while MAHMA had no effect (Figure $8 \mathrm{C})$.

\section{Inhibition of lipid peroxidation by NO also protects from UVA 1 -induced mitochondrial cytochrome $c$ release}

For further elucidation of the molecular mechanism responsible for the antiapoptotic effects of $\mathrm{NO}$ present during $\mathrm{UVA}_{1}$-exposure $\left(8 \mathrm{~J} / \mathrm{cm}^{2}\right)$, we examined events upstream of the caspase cascade. Using the Western blot technique we investigated the expression of the apoptosis relevant proteins $\mathrm{Bcl}-2$ and $\mathrm{Bax}$ as well as the release of holocytochrome $c$ from mitochondria into the cytoplasm as an early and pivotal signal in initiation of the apoptosis program. As shown in Figure 9A, UVA 1 -irradiation does not influence the amount of Bax protein. More importantly, during the time interval examined we find no increases of $\mathrm{Bcl}-2$ protein expression and a caspase-mediated cleavage of the antiapoptotic $\mathrm{Bcl}-2$ could not be demonstrated within the first $4 \mathrm{~h}$ after $\mathrm{UVA}_{1}$-irradiation (Figure 9B). In contrast, $2 \mathrm{~h}$ after $U_{V A_{1}}$-irradiation we found holocytochrome $c$ appearing in the cytoplasmic compartment and this remained for up to $4 \mathrm{~h}$ after $\mathrm{UVA}_{1}$-challenge (Figure 10A). Importantly, as shown in Figure 10B, this holocytochrome $c$ release was completely blocked when $U_{V A}$-irradiation of endothelial cells was performed in the presence of SNOC or any of the antioxidants, shown to inhibit lipid peroxidation (1 mM SNOC, $40 \mathrm{mM}$ histidine, $80 \mu \mathrm{M}$ MnTBAP, $2000 \mathrm{U} / \mathrm{ml}$ catalase), whereas the control compounds did not block the increases in holocytochrome $c$ release. 

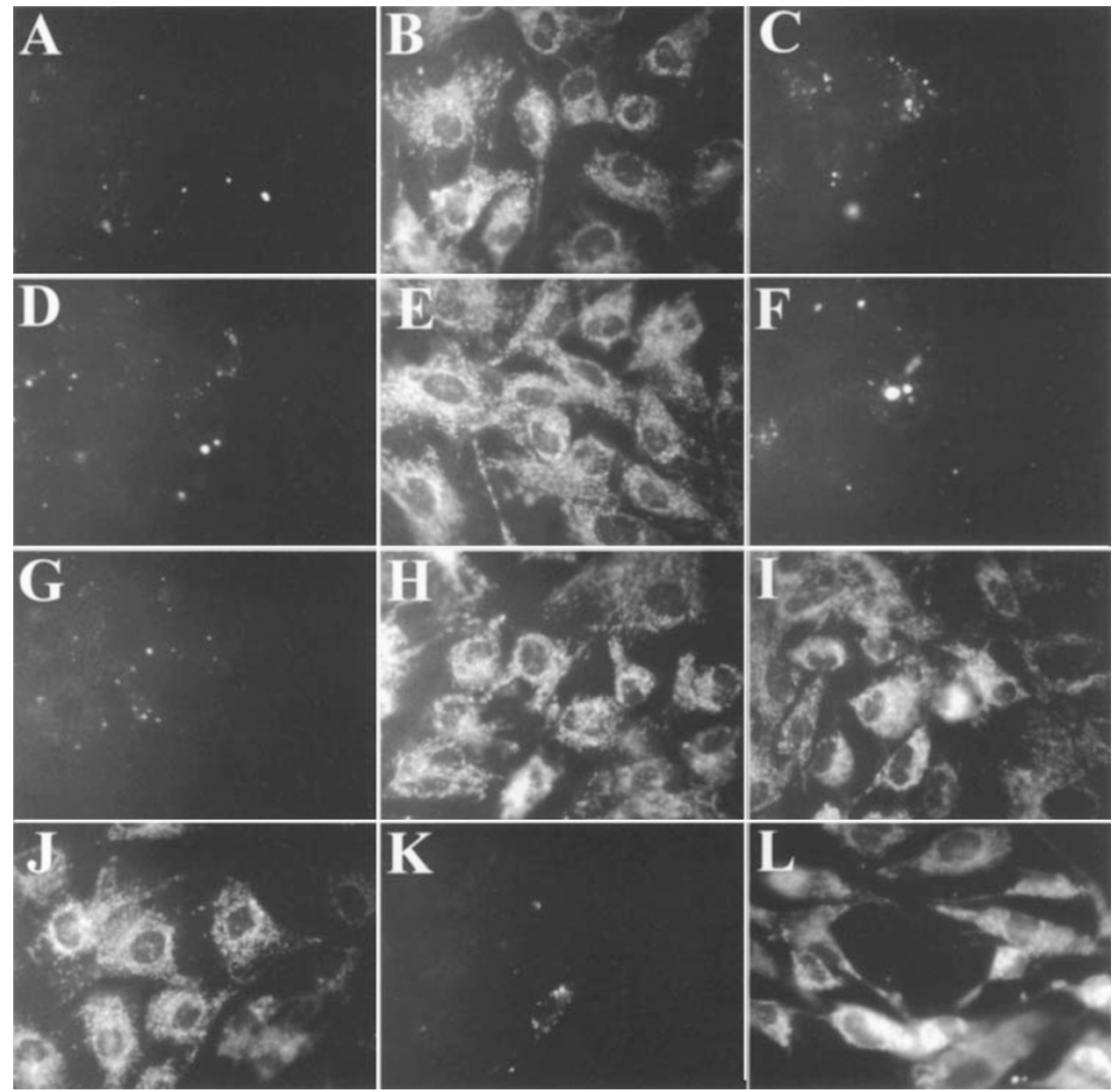

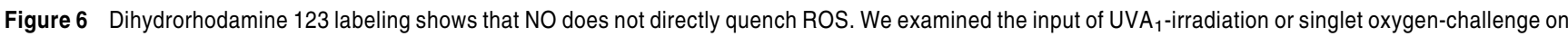
ROS mediated $\mathrm{H}_{2} \mathrm{O}_{2}$ formation in dihydrorhodamine 123 (DHR, $10 \mu \mathrm{M}$ ) labeled cells. Additionally, the role of $\mathrm{NO}$ as potential scavenger or reaction partner for the ROS formed was examined. Photomicrographs from experiments with $U_{V A}\left(8 \mathrm{~J} / \mathrm{cm}^{2}\right)$ are shown. Results obtained with the RB/hv-system were similar (data not shown). (A), Negative control, non-irradiated cells. (B), UVA 1 -irradiation leads to an increase in mitochondrial fluorescence. (C), Presence of histidine (40 mM) or (D), inhibition of SOD activity with DETC $(1 \mathrm{mM})$ or $(\mathbf{F})$, depletion of superoxide by MnTBAP $(80 \mu \mathrm{M})$ as well as $(\mathbf{G})$, peroxide depletion by catalase (2000 U/ml) fully inhibited fluorochrome formation. $(E)$, Addition of SOD $(1000 \mathrm{U} / \mathrm{ml})$ during the treatments gave no apparent alterations in fluorescence activity, and $(\mathrm{H})$ heatinactivated catalase had no inhibitory effect on UVA-induced fluorochrome formation. (I), Neither BHT $(10 \mu \mathrm{M})$ nor $(\mathrm{J})$, SNOC $(1 \mathrm{mM})$ inhibited the UVA -induced $^{-}$ fluorescence. (K), Cells treated as in (D) but additionally in the presence of the NO-donor SNOC (1 mM) show no increase in fluorochrome formation indicating that peroxynitrite is not produced. (L), positive control, 30 min incubation with $0.3 \mathrm{mM} \mathrm{H}_{2} \mathrm{O}_{2}$. In the absence of UVA $\mathrm{A}_{1}$-irradiation neither SNOC nor any of the other antioxidants lead to increased fluorescence due to rhodamine 123 formation (data not shown). Magnifications: $\times 650$

\section{Discussion}

The cytotoxic action of $U_{V A}$-radiation on mammalian cells is known to depend on the presence of oxygen. Multiple evidence exist that reactive oxygen species are involved. ${ }^{15}$ Studies with chemical probes have implicated the involvement of $\mathrm{H}_{2} \mathrm{O}_{2},{ }^{16} \mathrm{O}_{2} \cdot,{ }^{17} \mathrm{OH}^{\cdot},{ }^{18}$ and an important role for ${ }^{1} \mathrm{O}_{2}{ }^{13}$ in $\mathrm{UVA}_{1}$-mediated cytotoxicity. In biological environments singlet oxygen is highly reactive with a sufficiently long half-life to reach specific compartments. ${ }^{19}$ All ROS are potentially harmful to cells as they interact with and modify a broad spectrum of biomolecules. ${ }^{20}$ Thus, exposure of cells to ROS results in progressive cell damage by oxidative modification of various bio-molecules. $^{21}$
Free-radical-induced damage of membranes results in loss of membrane function caused by $\mathrm{UVA}_{1}$-radiation as well as radical-induced membrane damage using insults other than $U_{V A}$ radiation $^{22,23}$ correlates with cell death via apoptosis or necrosis. We recently observed that UVchallenge of normal human skin leads to the induction of iNOS expression in keratinocytes and capillary endothelial cells. ${ }^{24}$ High amounts of NO as produced by iNOS are known inducers of cell death via apoptosis or necrosis determined by the energy status of the respective cell. ${ }^{25,26}$ Thus, it was tempting to speculate that iNOS expression after UV challenge may contribute to cellular skin damage.

However, NO may also exert antiapoptotic activity and indeed we have shown recently, that the presence of endogenously or exogenously formed NO prior to $\mathrm{UVA}_{1}$ - 

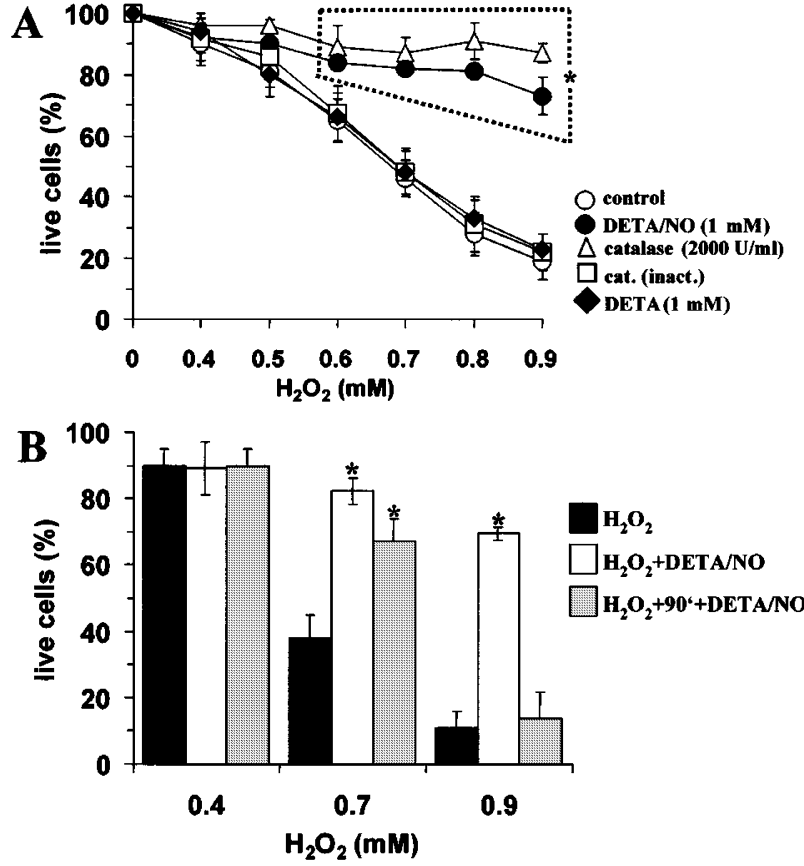

Figure 7 Nitric oxide fully protects from hydrogen peroxide induced toxicity. We examined the effects of exogenously applied nitric oxide ( $1 \mathrm{mM}$ DETA/NO) or catalase $(4000 \mathrm{U} / \mathrm{ml})$ as well as the controls DETA $(1 \mathrm{mM})$ or heat inactivated catalase on $\mathrm{H}_{2} \mathrm{O}_{2}$ induced endothelial cell death, respectively. (A) Incubation of endothelial cells with $\mathrm{H}_{2} \mathrm{O}_{2}(O)$ leads to concentrationdependent cell death. Hydrogen peroxide induced cell death was significantly reduced in the presence of catalase $(\triangle)$ as well as DETA/NO $(\mathbf{0})$, whereas neither DETA alone nor heat inactivated catalase $(\square)$ had any effects. Values in the dotted cage are statistically significant. (B) When incubating endothelial cells with the half-maximal toxic dose of $0.7 \mathrm{mH} \mathrm{H}_{2} \mathrm{O}_{2}$, DETA/NO significantly protected from cell death even when added $90 \mathrm{~min}$ after the toxic stimulus, whereas with $0.9 \mathrm{mM} \mathrm{H}_{2} \mathrm{O}_{2} \mathrm{DETA} / \mathrm{NO}$ at that concentration had no protective effects (gray bars). Black bars, incubation with $\mathrm{H}_{2} \mathrm{O}_{2}$ alone. White bars, incubation with $\mathrm{H}_{2} \mathrm{O}_{2}$ in the presence of $1 \mathrm{mM}$ DETA/NO. Values are the mean \pm S.D. of 3-6 individual experiments. ${ }^{*}, P<0.001$, as compared to $\mathrm{H}_{2} \mathrm{O}_{2}$ treated cell cultures $(O$, in $\mathbf{A}$ or black bars in $\mathbf{B})$

irradiation results in a strong increase of $\mathrm{Bcl}-2$ protein expression correlating with full protection from $\mathrm{UVA}_{1}$ induced apoptosis. ${ }^{10}$ We now provide evidence for protection even when $\mathrm{NO}$ is added up to $2 \mathrm{~h}$ after irradiation and also present data showing that here a different mechanism upstream of the apoptotic machinery is at work.

The time-course experiments using various antioxidants implicate a ROS cascade starting with $U_{V A}$-or Rose Bengal-induced ${ }^{1} \mathrm{O}_{2}$ formation, followed by generation of $\mathrm{O}_{2}{ }^{-}$; then $\mathrm{H}_{2} \mathrm{O}_{2}$ accumulation, and the latest step found to occur in our experiments was lipid peroxidation. Interestingly, and despite the close similarity of the chain of ROS formation both ultimately resulting in lipid peroxidation, the mode of cell death differs for the two types of treatment. This may be due to the lipophilic character of Rose Bengal which readily incorporates into cellular membranes. Thus, ${ }^{1} \mathrm{O}_{2}$ formation and subsequent reactions will occur within bio-membranes and may thus lead to rapid and irreversible destruction of membrane integrity, which is regarded as the hallmark event of necrosis. In contrast, UVA ${ }_{1}$ irradiation will lead to ${ }^{1} \mathrm{O}_{2}$ formation in many compartments of the cell mostly dependent on the presence of intracellular chromophores responsible for ${ }^{1} \mathrm{O}_{2}$ release. ${ }^{27,28}$ As long as energy equivalents are not leaking from the cytoplasm as is the case with necrosis, cells can undergo apoptosis as has been reported. ${ }^{25}$ It thus appears that here the decision for death by necrosis or apoptosis is not dominated by the type of molecular insult, but rather by the site of the damaging event.

Lipid peroxidation, found to represent a late step in the cascade, was decreased by the various antioxidants used as well as by exogenously applied NO donors, all of which inhibit the onset of necrosis or apoptosis. Examining events downstream of lipid peroxidation demonstrated a close positive correlation between the peroxidation of lipids and mitochondrial cytochrome $c$ leakage. Within the time frame given, $\mathrm{UVA}_{1}$-irradiation in the presence or absence of $\mathrm{NO}$ does neither decrease nor increase $\mathrm{Bcl}-2$ protein expression or caspase mediated $\mathrm{Bcl}-2$ cleavage, nor does the late addition of $\mathrm{NO}$ allow for gene up-regulation. Thus, in this experimental setup protection from cytochrome $c$ release by acute NO treatment strongly correlates with, and thus appears to be dominantly mediated by inhibition of lipid peroxidation.

Lipid peroxidation results from the net abstraction of an allylic hydrogen atom of an unsaturated fatty acid by an initiating radical species to generating a lipid radical. The lipid radical then reacts with $\mathrm{O}_{2}$ to generate an alkylperoxy radical (LOO) which can further react with another lipid to form another lipid radical that can also react with $\mathrm{O}_{2}$ and so on. ${ }^{29}$ Thus, a single initiating event can lead to the destruction/modification of numerous lipid molecules resulting in loss of membrane integrity. As shown, lipid peroxidation can be avoided or limited by inhibiting the generation of or quenching the initiating radical species by antioxidants, however, data presented do not corroborate such a role for NO but rather suggest a radical-chain terminating activity. The NO-radical ( $\mathrm{NO}$ ) reacts rapidly via simple radical-radical combination reactions with species possessing unpaired electrons as $\mathrm{O}_{2}, \mathrm{O}_{2}$ and $\mathrm{O}_{2} \cdot-$. The ability of $\mathrm{NO}$ to quench other radical species also allows it to terminate radical chain reactions. ${ }^{30}$ The reaction of $\mathrm{NO}$ with LOO species readily predominates over the much slower initiation of secondary peroxidation propagation reactions by LOO with vicinal unsaturated lipids, and when inhibiting lipid peroxidation propagation reactions, NO undergoes an initial termination reaction with organic peroxyl radicals to form organic peroxynitrates (LOONO). ${ }^{31}$

In summary, we present evidence that $\mathrm{NO}$ can prevent cell death as a consequence of UVA-induced onset of lipid peroxidation and ROS-formation. This finding bears significance in understanding protective responses in human skin exposed to excessive doses of sunlight. As during the first exposure to UV skin cells are usually not expressing iNOS, it is important to understand the protective mechanisms exerted by subsequent NO synthesis in the skin, a process which will help to minimize skin cell destruction. 

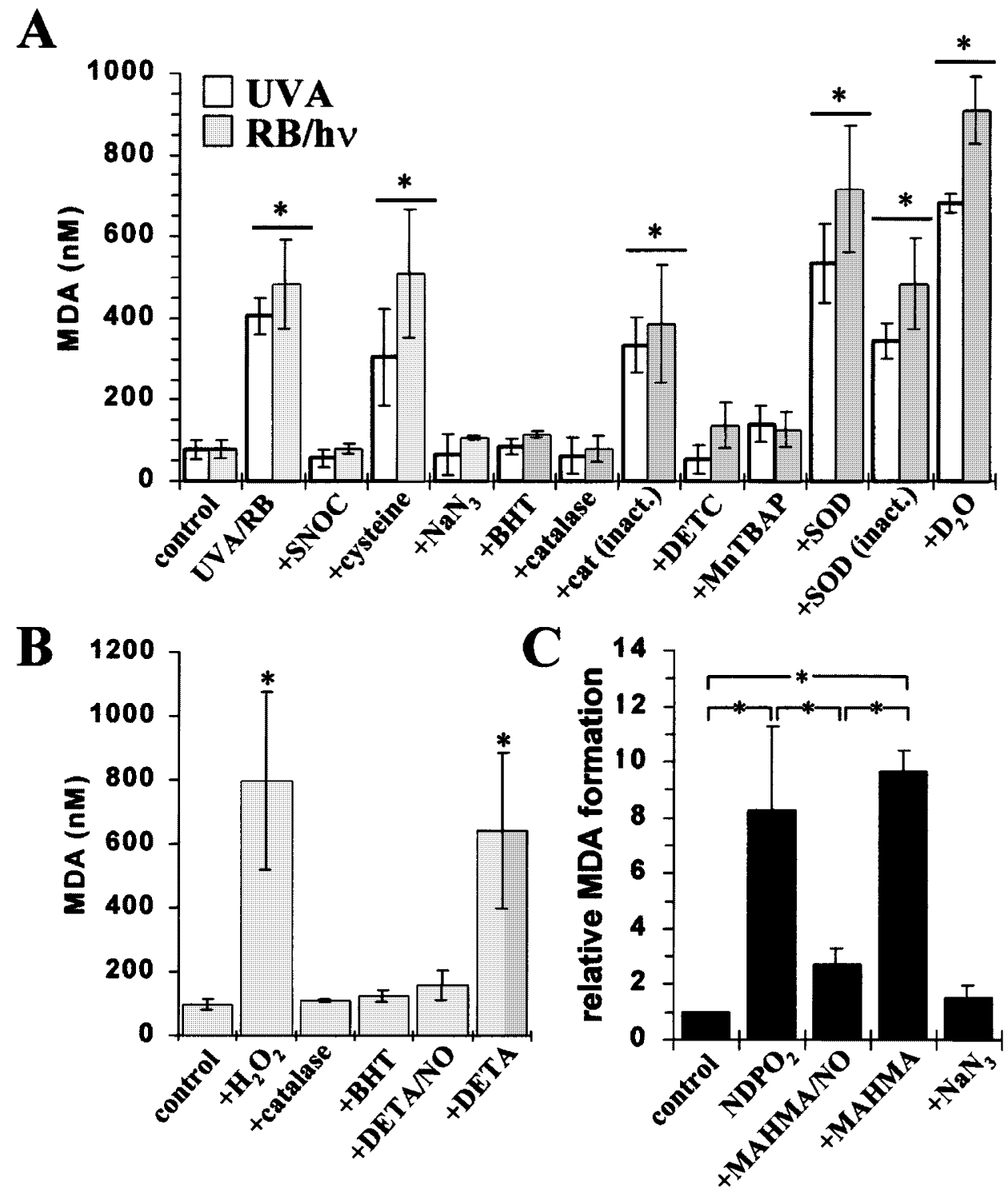

Figure 8 NO blocks lipid peroxidation. (A), Endothelial cells were irradiated with $\mathrm{UVA}_{1}$ (white bars, $10 \mathrm{~J} / \mathrm{cm}^{2}$ ) or treated with RB/hv (gray bars, $1.5 \mu \mathrm{M}$ ) or $(\mathbf{B}$ ), were incubated with $\mathrm{H}_{2} \mathrm{O}_{2}(0.9 \mathrm{mM})$ in the absence or presence of the respective additives and lipid peroxidation was assayed by measuring malonedialdehyde (MDA) formation. Additionally, lipid peroxidation was examined in liposomes $(\mathbf{C})$ after treatment with the endoperoxide $\mathrm{NDPO}_{2}$. (A), UVA $\mathrm{A}_{1}$-irradiation or RB/hv-challenge led to lipid peroxidation and compounds that protected cells from apoptosis or necrosis ( $1 \mathrm{mM} \mathrm{SNOC,} 20 \mathrm{mM} \mathrm{NaN}, 10 \mu \mathrm{M} \mathrm{BHT}, 2000 \mathrm{U} / \mathrm{ml}$ catalase, $1 \mathrm{mM}$ DETC, $80 \mu \mathrm{M}$ MnTBAP) also protected from $\mathrm{UVA}_{1}$ - or RB/h $v$-induced lipid peroxidation as seen by the reduction of MDA-levels to control values. All compounds shown to increase cell death such as SOD $(1000 \mathrm{U} / \mathrm{ml})$ or $\mathrm{D}_{2} \mathrm{O}$ enhanced lipid peroxidation. The control compounds cysteine $(1 \mathrm{mM})$, heat-inactivated catalase or SOD did not alter MDA formation. (B), As compared to the controls, incubation of endothelial cells with $\mathrm{H}_{2} \mathrm{O}_{2}$ led to an approximately eightfold increase in lipid peroxidation Incubation with hydrogen peroxide in the presence of DETA/NO $(1 \mathrm{mM})$ or catalase $(4000 \mathrm{U} / \mathrm{ml})$ significantly reduced formation of lipid peroxides to control values, where as the control agent DETA alone had no effects. (C), In liposomes, thermal decomposition $\left(37^{\circ} \mathrm{C}\right)$ of the endoperoxide $\mathrm{NDPO}_{2}(20 \mathrm{mM})$ led to a $6-11$-fold increase in lipid peroxidation, which was inhibited by $\mathrm{NaN}_{3}(20 \mathrm{mM})$ or by the $\mathrm{NO}$ donor MAHMA/NO $(5 \mathrm{mM})$ whereas the control compound MAHMA showed no effects. Values are the mean \pm S.D. of $3-6$ individual experiments. ${ }^{*}, P<0.001$

\section{Materials and Methods}

\section{Reagents}

Endothelial cell growth supplement (ECGS), Neutral Red, deuterium oxide (98\%), rabbit anti-human von Willebrand Factor (vWF) antiserum, monoclonal mouse anti- $\alpha$-tubulin antibody, Rose Bengal, histidine, mannitol, imidazole, dimethyl sulfoxide (DMSO), sodium azide, catalase, diethyldithiocarbamate (DETC), 3-amino-1,2,4- triazole (ATA), $\mathrm{H}_{2} \mathrm{O}_{2}$, and Hoechst dye $\mathrm{H} 33342$ were purchased from Sigma (Deisenhofen, Germany), rabbit anti-rat Bcl-2 antibody or rabbit anti-rat Bax antiserum from Pharmingen (San Diego, CA, USA), peroxidase-conjugated porcine anti-rabbit IgG from DAKO (Hamburg, Germany), and peroxidase-conjugated goat anti-mouse IgG from Zymed Laboratories (San Francisco, CA, USA), manganese (III) tetrakis(4-benzoic acid)porphyrin (MnTBAP), and manganese (III) tetrakis(1-methyl-4-pyridyl)porphyrin (MnTMPyP) from Alexis 

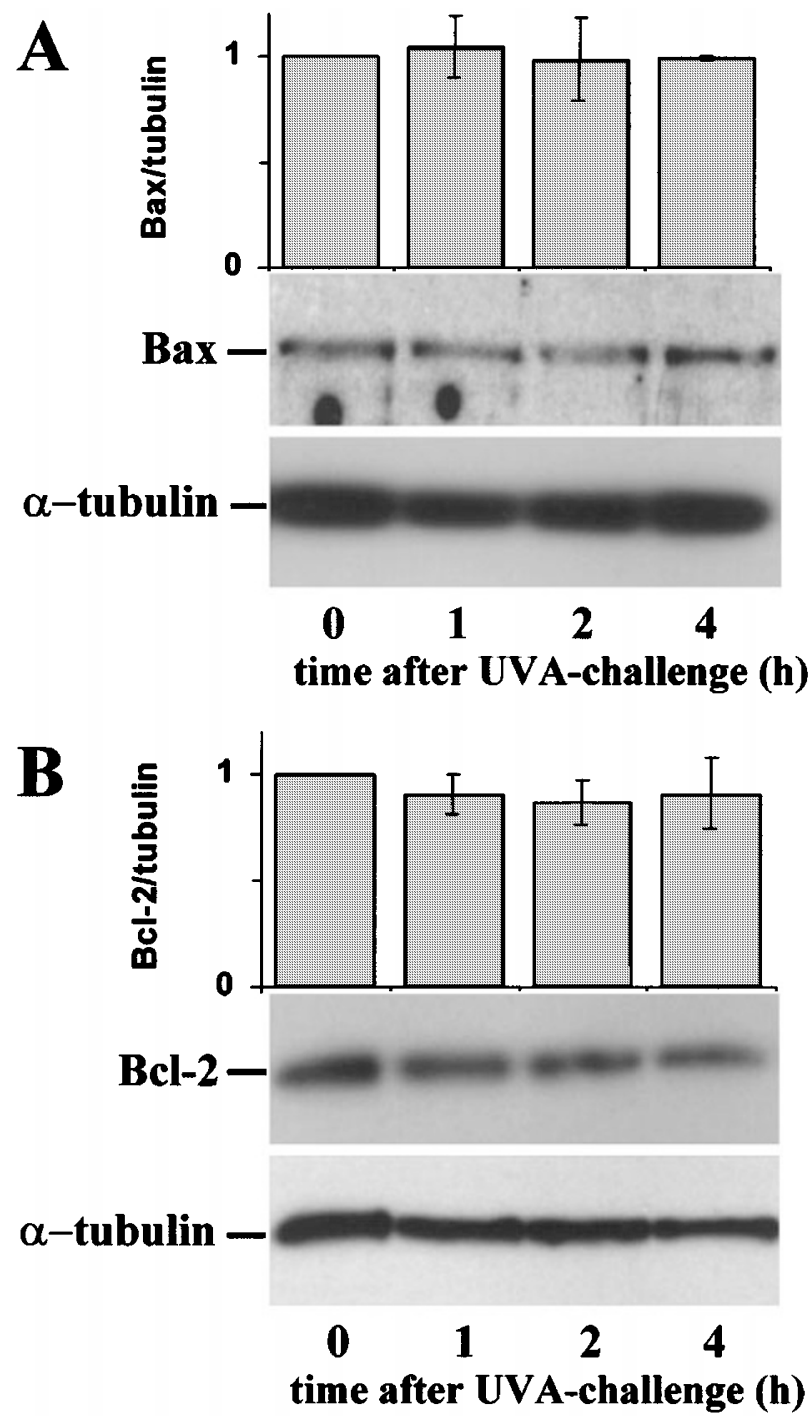

Figure $9 \mathrm{UVA}_{1}$-irradiation did not alter $\mathrm{Bax}$ or $\mathrm{Bcl}-2$ protein expression. Endothelial cells were irradiated with $\mathrm{UVA}_{1}\left(8 \mathrm{~J} / \mathrm{cm}^{2}\right)$ and within the first $4 \mathrm{~h}$, expression of the apoptosis-relevant proteins $\mathrm{Bcl}-2$ and Bax were studied by Western blot. Bax protein expression (A) or $\mathrm{Bcl}-2$ protein expression (B) were not altered. Bars represent the relative value of the Bax/ $\alpha$-tubulin- or Bcl-2/ $/$ tubulin-ratios obtained by densitometric analysis of visualized protein-bands from three individual experiments. Photomicrographs shown represent one out of three identical experiments

(Läufelfingen, Switzerland), diethylenetriamine and 2,[6]-di-tert-butylp-cresol (butylated hydroxytoluene, BHT) from Aldrich (Steinheim, Germany), dihydrorhodamine 123 (DHR) from Molecular Probes (Eugene, OR, USA), the monoclonal antibody $\mathrm{O} \times 43$ from Serotec (Camon, Wiesbaden, Germany), and the monoclonal mouse antiholocytochrome $c$ antibody from R\&D Systems (Heidelberg, Germany), protease inhibitor mix, trypsin, EDTA, fetal calf serum (FCS, endotoxin free), RPMI-1640 (endotoxin free), NADP, glucose-6phosphate, glucose-6-phosphate dehydrogenase from Boehringer Mannheim (Mannheim, Germany) or Gibco Laboratories (Eggenstein, Germany), and the ICE-inhibitor Z-VAD from Enzyme Systems (Livermore, CA, USA). The endoperoxide 3,3'-(1,4-naphthylidene)dipropionate $\left(\mathrm{NDPO}_{2}\right)$ was synthesized as described by $\mathrm{Di}$ Mascio and Sies. ${ }^{32}$ The NO donors (Z)-1-[N-(2-aminoethyl)- $N-(2$ -
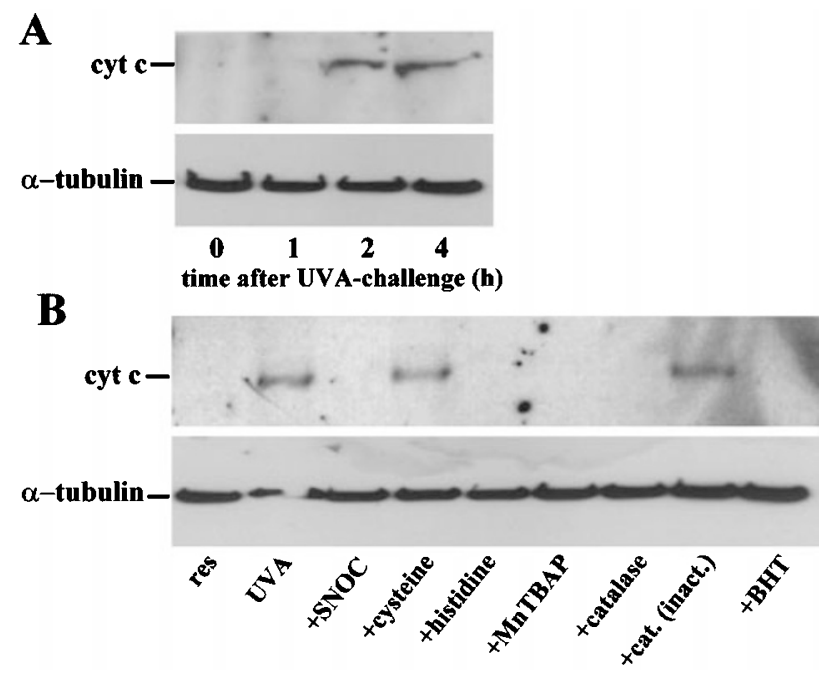

Figure 10 Nitric oxide prevents $U_{V A}$-induced mitochondrial cytochrome $c$ leakage. To correlate $U_{V A}$-induced apoptosis with lipid peroxidation, cells were irradiated with $U_{V A}\left(8 \mathrm{~J} / \mathrm{cm}^{2}\right)$ in the presence or absence of the NO donor SNOC or antioxidants. Within the first $4 \mathrm{~h}$ after irradiation, release of holocytochrome $c$ from mitochondria into the cytoplasm was studied by Western blot. (A), Two hours after UVA $_{1}$-irradiation holocytochrome $c$ appeared in the cytoplasm and remained at comparable level at $4 \mathrm{~h}$. (B), As determined $4 \mathrm{~h}$ after UVA-irradiation, cytoplasmic appearance of holocytochrome $c$ was completely inhibited in the presence of SNOC (1 mM) or any of the agents previously shown to inhibit cell death and lipid peroxidation $(40 \mathrm{mM}$ histidine, $80 \mu \mathrm{M}$ MnTBAP, $2000 \mathrm{U} / \mathrm{ml}$ catalase), whereas control compounds ( $1 \mathrm{mM}$ cysteine, heat-inactivated catalase) had no effects on mitochondrial holocytochrome $c$ release. Photomicrographs shown represent one out of three identical experiments

ammonioethyl)amino]diazen-1-ium-1,2-diolate (DETA/NO), (Z)-1-\{Nmethyl- $N$-[6-( $N$-methylammoniohexyl)amino] diazen-1-ium-1,2-diolate (MAHMA/NO), and S-nitrosocysteine (SNOC) were synthesized as described previously. ${ }^{33,34}$ The iNOS inhibitor L-N ${ }^{5}$-(1-iminoethyl)ornithin (NIO) was a kind gift from Boehringer Mannheim. As $U_{V A}$ source we used a Sellas-2,000 or Sellas-4000 lamp (Sellas Medizinische Geräte, Gevelsberg, Germany) emitting the $U_{V A}$ spectrum $(340-390 \mathrm{~nm})$.

\section{Endothelial cells}

Endothelial cells (EC) were isolated by outgrowth from male Wistar rat aortic rings as described previously. ${ }^{9}$ Briefly, aortic segments were placed on top of a collagen gel (1.8 mg collagen $/ \mathrm{ml})$ in 24-well tissue culture plates and incubated in RPMI 1640/20\% FCS supplemented with $100 \mu \mathrm{g} \mathrm{ECGS} / \mathrm{ml}$ for 5 days. Aortic explants were then removed, cells detached with $0.25 \%$ collagenase in HBSS and replated onto plastic culture dishes in RPMI 1640/20\% FCS. Cells were subcultured for up to eight passages, and removal from culture dishes for each passage was performed by treatment with trypsin/EDTA. Cellular characterization of cultured endothelial cells was performed by determination of the endothelium characteristic antigenic phenotype using the anti-vWF antiserum, the endothelium-specific monoclonal antibody $\mathrm{O} \times 43$, and the respective peroxidase-conjugated secondary antibodies as described previously. ${ }^{35}$

\section{Singlet oxygen production}

Intracellular release of singlet oxygen was achieved by photoexcitation of solutions containing endothelial cells and varying concentrations of 
Rose Bengal (RB/hv) with a commercially available white lamp from a fixed distance. ${ }^{36}$ Briefly, endothelial cells were incubated for $15 \mathrm{~min}$ with Rose-Bengal in the dark at $37^{\circ} \mathrm{C}$ in RPMI 1640 without FCS and phenol red. Cells were then irradiated for 5 min using the $500 \mathrm{~W}$ white light source in a fixed distance of $40 \mathrm{~cm}$. Alternatively, singlet oxygen was generated by chemiexcitation via thermodecomposition of the endoperoxide $\mathrm{NDPO}_{2}{ }^{12,32}$

\section{Experimental design}

All measurements were performed with cells from passages 2-8. Endothelial cells were cultured in 12-well tissue culture plates $\left(2 \times 10^{5}\right)$ or on 8-well chamber-Tec glass slides $\left(1 \times 10^{4}\right)$ in a humidified incubator at $37^{\circ} \mathrm{C}$ in RPMI $1640 / 20 \%$ FCS. Endothelial apoptosis was induced by irradiation with $\mathrm{UVA}_{1}\left(2-10 \mathrm{~J} / \mathrm{cm}^{2}\right)$ or $\mathrm{H}_{2} \mathrm{O}_{2}$ challenge (0.1-0.9 mM) whereas necrosis was achieved by singlet oxygen generated from Rose Bengal at the concentrations indicated plus lighttreatment $(\mathrm{RB} / \mathrm{h} v)$. During or at indicated time points after $\mathrm{UVA}_{1}$ irradiation, $\mathrm{RB} / \mathrm{h} v$ challenge or hydrogen peroxide incubation resident endothelial cells were incubated with the respective additives at concentrations indicated and $24 \mathrm{~h}$ after irradiation the relative number of living endothelial cells was detected by neutral red staining as described previously. ${ }^{10}$ Additionally, viability of endothelial cells was routinely controlled at the beginning and the end of every experiment using the trypan blue exclusion assay or propidium iodide staining. Viable cells were defined as cells excluding trypan blue or propidium iodide and positive for respiratory activity as determined by neutral red.

\section{Detection of apoptotic or necrotic cells}

At different time points $(1-24 \mathrm{~h})$ after $U_{V A}$-irradiation $\left(2-10 \mathrm{~J} / \mathrm{cm}^{2}\right)$, $\mathrm{RB} / \mathrm{h} v$-challenge or $\mathrm{H}_{2} \mathrm{O}_{2}$ incubation endothelial cells grown in 12well culture plates were washed with PBS, stained with Hoechst dye $\mathrm{H} 33342(8 \mu \mathrm{g} / \mathrm{ml})$ and $/$ or propidium iodide $(0.5 \mu \mathrm{g} / \mathrm{ml})$ for $5 \mathrm{~min}$ and nuclei or necrotic cells were visualized using a Zeiss fluorescence microscope, respectively. In each sample a minimum of 400 cells was counted and condensed or fragmented nuclei as well as necrotic cells were expressed as per cent of total cells.

\section{Detection and quantification of nuclear DNA fragmentation}

DNA strand breaks of cells grown on 8-well chamber-tec slides were visualized by the in situ nick-translation method ${ }^{37} 1-24 \mathrm{~h}$ after UVAirradiation $\left(2-10 \mathrm{~J} / \mathrm{cm}^{2}\right)$. In acetone fixed cells endogenous peroxidase activity was blocked with methanol $+0.3 \% \quad \mathrm{H}_{2} \mathrm{O}_{2}$ for $30 \mathrm{~min}$. The nick-translation mixture contained $3 \mu \mathrm{M}$ biotin-dUTP, $5 \mathrm{U} / 100 \mu \mathrm{l}$ Kornberg polymerase, $3 \mu \mathrm{M}$ each dGTP, dATP, dCTP, $50 \mathrm{mM}$ Tris-HCL, pH 7.5, $5 \mathrm{mM} \mathrm{MgCl}_{2}, 0.1 \mathrm{mM}$ dithiothreitol, and reaction was performed at room temperature for $20 \mathrm{~min}$. Slides were washed in PBS and processed for immunocytochemical detection of biotin-labeled UTP by peroxidase-labeled avidin, followed by an enzyme reaction using $D A B$ as substrate. In each sample a minimum of 500 cells were counted and labeled nuclei were expressed as per cent of total nuclei.

\section{Use of antioxidants}

For examining the role of reactive oxygen species (ROS) in cytotoxicity during or at time points indicated after $U_{V A}$-irradiation, $\mathrm{RB} / \mathrm{h} v$ challenge or $\mathrm{H}_{2} \mathrm{O}_{2}$ incubation, endothelial cells were incubated with inhibitors of the respective ROS class.
Inhibition of singlet oxygen $\left({ }^{1} \mathrm{O}_{2}\right)$ action was achieved by addition of sodium azide $(20 \mathrm{mM})$, histidine $(40 \mathrm{mM})$, or imidazole $(40 \mathrm{mM})$. In contrast, increasing of ${ }^{1} \mathrm{O}_{2}$ half-life and thus its action was achieved in the presence of deuterated water $\left(\mathrm{D}_{2} \mathrm{O}, 99 \%\right.$ atom $){ }^{38-40}$ These agents were added to the cells $10 \mathrm{~min}$ prior to, were present during, and for $5 \mathrm{~min}$ after the respective procedure (10/present/5). To deplete superoxide anions $\left(\mathrm{O}_{2}{ }^{-}\right)$SOD $(1000 \mathrm{U} / \mathrm{ml} ; 60 /$ present/5) but also the $\mathrm{O}_{2} \cdot{ }^{-}$- quencher MnTBAP (80 $\mu \mathrm{M}$; 0/absent/30) or MnTMPyP (150 $\mu \mathrm{M}$; $0 /$ absent/30) ${ }^{41,42}$ were used. As a control, heat-inactivated SOD $\left(10 \mathrm{~min}\right.$ at $\left.100^{\circ} \mathrm{C}\right)$ was used, and to inhibit the cytosolic $\mathrm{Cu} / \mathrm{Zn}$ SOD the powerful inhibitor diethyldithiocarbamate $(1 \mathrm{mM}$; 30/present/5) was used. ${ }^{43}$ Hydrogen peroxide $\left(\mathrm{H}_{2} \mathrm{O}_{2}\right)$ was degraded by catalase (2000 U/ml; 60/absent/5), and as a control, heat-inactivated catalase $\left(20 \mathrm{~min}\right.$ at $\left.100^{\circ} \mathrm{C}\right)$ was used, and intracellular catalase activity was inhibited using 3-amino-1,2,4-triazole $\left(500 \mu \mathrm{M} ; 30 /\right.$ present/5) ${ }^{44}$ Inhibition of lipid peroxide formation was achieved with $\mathrm{BHT}(10 \mu \mathrm{M}$; $30 /$ present $/ 5),{ }^{45}$ and for hydroxyl radical $\left(\mathrm{OH}^{*}\right)$ quenching DMSO (100 mM; 30/present/5) or mannitol $(100 \mathrm{mM}$; 30/present/5) were used. ${ }^{46,47}$ In experiments examining $\mathrm{H}_{2} \mathrm{O}_{2}$ toxicity the respective agents ( $1 \mathrm{mM}$ DETA/NO, $1 \mathrm{mM}$ DETA, $4000 \mathrm{U} / \mathrm{ml}$ catalase, heatinactivated catalase) were added $10 \mathrm{~min}$ prior to the addition of hydrogen peroxide and were present during the $24 \mathrm{~h}$ of incubation.

In experiments examining the time-course of ROS action the respective agents were added for $30 \mathrm{~min}$ to the cell cultures at the different time points indicated after the toxic insult. In the case of incubation with $\mathrm{H}_{2} \mathrm{O}_{2}$ the respective agents ( $1 \mathrm{mM}$ DETA/NO, $1 \mathrm{mM}$ DETA, $4000 \mathrm{U} / \mathrm{ml}$ catalase, heat-inactivated catalase) were added to the cell cultures for $30 \mathrm{~min}$ after $90 \mathrm{~min}$ of incubation with $0.4,0.7$ or $0.9 \mathrm{mM} \mathrm{H}_{2} \mathrm{O}_{2}$, then cell cultures were washed twice with PBS and grown in culture medium for $24 \mathrm{~h}$. At the concentrations used, none of the compounds mentioned above showed any cytotoxic effects towards the EC within the incubation time.

\section{Detection of intracellular $\mathrm{H}_{2} \mathrm{O}_{2}$}

Intracellular $\mathrm{H}_{2} \mathrm{O}_{2}$ formation was visualized using the fluorescent dye dihydrorhodamine $123(\mathrm{DHR})$. Endothelial cells $\left(1 \times 10^{5}\right)$ in 12 well tissue culture plates were loaded with DHR $(10 \mu \mathrm{M})$ for $45 \mathrm{~min}$ and washed with PBS before treatment with $\mathrm{UVA}_{1}$ or $\mathrm{RB} / \mathrm{h} v$. During the intracellular release of $\mathrm{H}_{2} \mathrm{O}_{2}$, reduced DHR is irreversibly oxidized and converted to the fluorescent compound rhodamine $123 .{ }^{48}$ Between 20 and $120 \mathrm{~min}$ after $\mathrm{UVA}_{1}$-irradiation rhodamine 123 formation was constant and was visualized using a Zeiss fluorescence microscope.

\section{Detection of lipid peroxidation in UVA $\mathrm{A}_{1}$-irradiated endothelial cells and measurement of microsomal lipid peroxidation}

Resting endothelial cells $\left(1 \times 10^{6}\right)$ in 6 -well tissue culture plates were irradiated with $\mathrm{UVA}_{1}\left(8 \mathrm{~J} / \mathrm{cm}^{2}\right)$, were exposed to $\mathrm{RB} / \mathrm{h} v(1.5 \mu \mathrm{M})$ or incubated with $\mathrm{H}_{2} \mathrm{O}_{2}(0.9 \mathrm{mM})$ in the absence or presence of the respective additives at the concentrations indicated. One hundred and twenty or $60 \mathrm{~min}$ after irradiation lipid peroxidation was stopped by addition of $\mathrm{BHT}(10 \mu \mathrm{M})$, respectively. Cells were harvested and lysed by repeated freezing and thawing. Malonedialdehyde (MDA) equivalents were estimated via the formation of thiobarbituric acid (TBA)-reactive substances using $\varepsilon_{535}=156 \mathrm{mM}^{-1} \mathrm{~cm}^{-1} .49$

Additionally, in a cell-free system lipid peroxidation was initiated in liposomes $(0.5 \mathrm{mg}$ protein $/ \mathrm{ml}$ ) by singlet oxygen generated by thermal decomposition from $\mathrm{NDPO}_{2}(20 \mathrm{mM})$ with premixed ADP $(1 \mathrm{mM}) /$ $\mathrm{FeCl}_{3}(10 \mu \mathrm{M})$, and NADPH regenerating system, containing NADPH $(0.4 \mathrm{mM})$, glucose-6-phosphate $(10 \mathrm{mM})$, glucose-6-phosphate dehydrogenase $(5 \text { units } / \mathrm{ml})^{50}$ in the presence or absence of the NO donor 
MAHMA/NO (5 mM; 1-2 min half-life for NO release at $37^{\circ} \mathrm{C}$ ), denitrosylated MAHMA/NO (MAHMA, $5 \mathrm{mM})$, sodium azide $(20 \mathrm{mM})$ or NDP $(20 \mathrm{mM})$ alone. Lipid peroxidation was assayed as described above.

\section{Western-blot analysis}

Resting or $\mathrm{UVA}_{1}$-irradiated $\left(8 \mathrm{~J} / \mathrm{cm}^{2}\right)$ endothelial cells $\left(4 \times 10^{7}\right)$, irradiated in the presence or absence of the compounds indicated, were detached after an incubation time of 1,2 or $4 \mathrm{~h}$ by trypsin treatment, and washed twice with ice-cold PBS. The cell pellets were suspended in three volumes of ice-cold isolation buffer $(0.25 \mathrm{M}$ saccharose, $10 \mathrm{mM}$ triethanolamine/ $\mathrm{HCl}, 5 \mathrm{mM} \mathrm{KH}_{2} \mathrm{PO}_{4}, 20 \mathrm{mM} \mathrm{KCl}$, $2 \mathrm{mM}$ EDTA, $5 \mathrm{mM} \mathrm{MgCl}_{2}$, $\mathrm{pH}$ 7.0) supplemented with the protease inhibitor mix from Boehringer. After $15 \mathrm{~min}$ on ice, the cells were disrupted by douncing in a $2 \mathrm{ml}$ glass douncer. Intact cells and nuclei were separated from cytosolic fraction by two centrifugation steps $(10 \mathrm{~min}$ at $2000 \times \mathrm{g}$ and $25 \mathrm{~min}$ at $16500 \times \mathrm{g}$ ). Pellets or mitochondria-free supernatants were mixed with the sample buffer (Novex, San Diego, CA, USA). Proteins (50 $\mu \mathrm{g}$ per lane taken from the pellet fraction for $\mathrm{Bcl}-2$ or Bax determination or $100 \mu \mathrm{g}$ per lane taken from the mitochondria-free supernatant for holocytochrome $c$ determination) were separated by electrophoresis in a gradient (4$12 \%$ ) bis-tris-polyacrylamide gel with MOPS-SDS running buffer (Novex) and transferred to nitrocellulose membranes. Further incubations of the blots were: $1 \mathrm{~h}$ with blocking buffer ( $2 \% \mathrm{BSA}, 5 \%$ non-fat milk powder, $0.1 \%$ Tween 20 in PBS-buffer), $1 \mathrm{~h}$ with a $1: 1000$ dilution of the monoclonal mouse anti-holocytochrome $c$ antibody or the rabbit anti-Bcl-2 or rabbit anti-Bax antiserum, washed, $1 \mathrm{~h}$ with a $1: 1000$ dilution of the secondary horseradish peroxidase conjugated goat anti-mouse IgG antibody or horseradish peroxidase conjugated porcine anti-rabbit IgG antibody. Finally, blots were incubated for 5 min in ECL reagent (Pierce, Rockford, IL, USA), placed into a plastic bag and exposed to an enhanced autoradiographic film. To control equal loading of total protein in all lanes, blots were stained with a $1: 2000$ solution of the mouse anti $\alpha$-tubulin antibody. The secondary horseradish peroxidase conjugated goat anti-mouse IgG antibody was diluted 1:2000 prior to use.

\section{Statistical analysis}

Data are given as means \pm S.D. Values were calculated using analysis with Student's t-test (two-tailed for independent samples).

\section{Acknowledgements}

We thank Christa-Maria Wilkens-Roth, Annette Reimann, Marija Lenzen, and Ulla Lammersen for technical assistance, and Martha Turken for photographic assistance. This study was supported by grants from the Deutsche Forschungsgemeinschaft (SFB 503, A3 and B1) and by NFCR.

\section{References}

1. Passchier WF and Bosnjakovic BFM (1987) Human Exposure to Ultraviolet Radiation. Amsterdam

2. Webb RB (1977) Lethal and mutagenic effects of near-ultraviolet radiation. In Photochemistry and Photobiology Reviews. Smith KC, ed. (New York: Plenum) pp. $169-262$

3. Tyrrell RM and Keyse SM (1990) The interaction of UVA radiation with cultured cells. J. Photochem. Photobiol. 4B: 349-361
4. Black HS (1987) Potential involvement of free radical reactions in ultraviolet lightmediated cutaneous damage. Photochem. Photobiol. 46: 213-221

5. Adams JM and Cory S (1998) The Bcl-2 protein family: arbiters of cell survival. Science 281: $1322-1326$

6. Kim Y-M, Bombeck CA and Billiar TR (1999) Nitric oxide as a bifunctional regulator of apoptosis. Circ. Res. 84: 253-256

7. Förstermann U, Closs EI, Pollock JS, Nakane M, Schwarz P, Gath I and Kleinert H (1994) Nitric oxide synthase isoenzymes. Characterisation, purification, molecular cloning, and functions. Hypertension 23: 1121-1131

8. Kröncke K-D, Fehsel K and Kolb-Bachofen V (1995) Inducible nitric oxide synthase and its product nitric oxide, a small molecule with complex biological activities. Biol. Chem. 376: 327-343

9. Suschek C, Rothe H, Fehsel K, Enczmann J and Kolb-Bachofen V (1993) Induction of a macrophage-like nitric oxide synthase in cultured rat aortic endothelial cells. J. Immunol. 151: 3283-3291

10. SuschekCV, KrischelV, Bruch-Gerharz D, Berendji D, Krutmann J, Kröncke K-D and Kolb-Bachofen V (1999) Nitric oxide fully protects against UVA-induced apoptosis in tight correlation with Bcl-2 up-regulation. J. Biol. Chem. 274:61306137

11. Klotz L-O, Pellieux C, Briviba K, Pierlot C, Aubry J-M and Sies H (1999) Mitogenactivated protein kinase (p38, JNK-, ERK-) activation pattern induced by extracellular and intracellular singlet oxygen and UVA. Eur. J. Biochem. 260: 917-922

12. Briviba K, Klotz L-O and Sies H (1997) Toxic and signaling effects of photochemically or chemically generated singlet oxygen in biological systems. Biol. Chem. 378: 1259-1265

13. Tyrrell RM and Pidoux M (1989) Singlet oxygen involvement in the inactivation of cultured human fibroblasts by UVA ( $334 \mathrm{~nm}, 365 \mathrm{~nm})$ and near-visible $(405 \mathrm{~nm})$ radiation. Photochem. Photobiol. 49: 407-412

14. Crow JP (1997) Dichlorodihydrofluorescein and dihydrorhodamine 123 are sensitive indicators of peroxynitrite in vitro: implications for intracellular measurement of reactive nitrogen and oxygen species. Nitric Oxide 1: 145-157

15. Danpure HJ and Tyrrell RM (1976) Oxygen dependence of near-UV (365 nm) lethality and the interaction of near-UV and X-rays in two mammalian cell lines. Photochem. Photobiol. 23: 171-177

16. McCormick JP, Fischer JR and Pachlatko JP (1976) Characterization of a celllethal product from the photooxidation of tryptophan: hydrogen peroxide. Science 191: 468-469

17. Czochralska B, Kamczynski W, Bartosz G and Shugar D (1984) Oxidation of excited-state NADH and NAD dimer in aqueous medium involvement of $\mathrm{O}_{2}{ }^{-}$as a mediator in the presence of oxygen. Biochim. Biophys. Acta. 801: 403-409

18. Peak JG, Peak MJ and Foote CS (1982) Effects of glycerol upon the biological action of near-ultraviolet light: spectra and concentration dependence for transforming DNA and for Escherichia coli B/r. Photochem. Photobiol. 3: 413416

19. Kanofsky JR (1989) Singlet oxygen production by biological systems. ChemBiol. Interact. 70: 1-28

20. Janssen YMW, Van Houten B, Borm PJA and Mossman BT (1993) Biology of Disease: cell and tissue responses to oxidative damage. Lab. Invest. 69: 261 274

21. Sies H (1986) Biochemistry of oxidative stress. Angew. Chem. Int. Ed. 25:10581071

22. Ramakrishnan N, McClain DE and Catravas GN (1993) Membranes as sensitive targets in thymocyte apoptosis. Int. J. Radiat. Biol. 63: 693-701

23. Forrest VJ, Kang Y-H and McClain DE (1994) Oxidative stress-induced apoptosis prevented by Trolox. Free Radical Biol. Med. 16: 675-684

24. Kuhn A, Fehsel K, Lehmann P, Krutmann J, Ruzicka T and Kolb-Bachofen V (1998) Aberrant timing in epidermal expression of inducible nitric oxide synthase after UV-irradiation in Lupus patients. J. Invest. Dermatol. 111: 149-153

25. Leist M, Single B, Castoldi AF, Kühnle P and Nicotera P (1997) Intracellular adenosine triphosphate (ATP) concentrations: A switch in the decision between apoptosis and necrosis. J. Exp. Med. 185: 1481-1486

26. Kröncke K-D, Fehsel K and Kolb-Bachofen V (1997) Nitric oxide: cytotoxicity versus cytoprotection: How, why, when, and where? Nitric Oxide Biol. Chem. 1: $107-120$

27. Ryter SW and Tyrrell RM (1998) Singlet molecular oxygen ((1)O2): a possible effector of eukaryotic gene expression. Free Radic Biol. Med. 24: 1520-1534

28. McCaughan JrJS, (1999) Photodynamic therapy: a review. Drugs Aging 15:4968 
29. Fukuto JM, Cho JY and Switzer CH (2000) The chemical properties of nitric oxide and related nitrogen oxides. In: Nitric Oxide: Biology and Pathobiology. Ignarro LJ, ed. (San Diego: Academic Press) pp. 23-40

30. Darley-Usmar VM, Patel RP, O'Donnell VB and Freeman BA (2000) Antioxidant actions of nitric oxide. In: Nitric Oxide: Biology and Pathobiology. Ignarro LJ, ed. (San Diego: Academic Press) pp. 265-276

31. Miranda KM, Espey MG, Jourd'heuil D, Grisham MB, Fukuto J, Feelisch M and Wink DA (2000) The chemical biology of nitric oxide. In: Nitric Oxide: Biology and Pathobiology. Ignarro LJ, ed. (San Diego: Academic Press) pp. 41-56

32. Di Mascio P and Sies $H$ (1989) Quantification of singlet oxygen generated by thermolysis of 3,3'-(1,4-naphthylidene)dipropionate. Monomol and dimol photoemission and the effects of 1,4-diazabicyclo [2.2.2] octane. J. Am. Chem. Soc. 111: 2909-2914

33. Kröncke K-D and Kolb-Bachofen V (1996) Detection of nitric oxide interaction with zinc finger proteins. Meth. Enzymol. 269: 279-284

34. Hrabie JA, Klose JR, Wink DA and Keefer LK (1993) New nitric oxide-releasing zwitterions derived from polyamines. J. Org. Chem. 58: 1472-1476

35. Suschek C, Fehsel K, Kröncke K-D, Sommer A and Kolb-Bachofen V (1994) Primary cultures of rat capillary endothelial cells: constitutive and cytokineinducible macrophage-like nitric oxide synthases are expressed and activities regulated by glucose concentration. Am. J. Pathol. 145: 485-695

36. Klotz L-O, Briviba K and Sies H (1997) Singlet oxygen mediates the activation of JNK by UVA radiation in human skin fibroblasts. FEBS Lett. 408: 289-291

37. Fehsel K, Kolb-Bachofen V and Kolb H (1991) Analysis of TNF-alpha-induced DNA strand breaks at the single cell level. Am. J. Path. 139: 251-157

38. Kaiser S, DiMascio P, Murphy ME and Sies H (1990) Physical and chemical scavenging of singlet molecular oxygen by tocopherols. Arch. Biochem. Biophys. 277: 101-108

39. Egorov SY, Kurella EG, Boldyrev AA and Krasnovsky AAJ (1997) Quenching of singlet molecular oxygen by carnosine and related antioxidants. Monitoring 1270-nm phosphorescence in aqueous media. Biochem. Mol. Biol. Int. 41:687694
40. Michaeli A and Feitelson J (1994) Reactivity of singlet oxygen toward amino acids and peptides. Photochem. Photobiol. 59: 284-289

41. Faulkner KM, Stevens RD and Fridovich I (1994) Characterization of Mn(III) complexes of linear and cyclic desferrioxamines as mimics of superoxide dismutase activity. Arch. Biochem. Biophys. 310: 341-346

42. Faulkner KM, Liochev SI and Fridovich I (1994) Stable Mn(III) porphyrins mimic superoxide dismutase in vitro and substitute for it in vivo. J. Biol. Chem. 269: $23471-23476$

43. Heikkila RE, Cabbat FS and Cohen G (1976) In vivo inhibition of superoxide dismutase in mice by diethyldithiocarbamate. J. Biol. Chem. 251:2182-2185

44. Williams RN, Delamere NA and Paterson CA (1985) Inactivation of catalase with 3-amino-1,2,4-triazole: an indirect irreversible mechanism. Biochem. Pharmacol. 34: $3386-3389$

45. Bose B, Agarwal S and Chatterjee SN (1989) UV-A induced lipid peroxidation in liposomal membrane. Radiat. Environ. Biophys. 28: 59-65

46. Babbs CF and Griffin DW (1989) Scatchard analysis of methane sulfinic acid production from dimethyl sulfoxide: a method to quantify hydroxyl radical formation in physiologic systems. Free Radic. Biol. Med. 6: 493-503

47. Chaturvedi V, Wong B and Newman SL (1996) Oxidative killing of Cryptococcus neoformans by human neutrophils. Evidence that fungal mannitol protects by scavenging reactive oxygen intermediates. J. Immunol. 156: 3836-3840

48. Royall JA and Ischiropoulos $\mathrm{H}$ (1993) Evaluation of $2^{\prime}, 7^{\prime}$-dihydrofluorescin and dihydrorhodamine 123 as fluorescent probes for intracellular $\mathrm{H}_{2} \mathrm{O}_{2}$ in cultured endothelial cells. Arch. Biochem. Biophys. 302: 348-355

49. Knight JA, Pieper RK and McClellan L (1988) Specificity of the thiobarbituric acid reaction: its use in studies of lipid peroxidation. Clin. Chem. 34: 2433-2438

50. Scheschonka A, Murphy ME and Sies H (1990) Temporal relationships between the loss of vitamin $E$, protein sulfhydryls and lipid peroxidation in microsomes challenged with different prooxidants. Chem-Biol Interact. 74: 233-252 